\title{
Distribution and habitat characteristics of pinnipeds and polar bears in the Svalbard Archipelago, 2005-2018
}

\author{
Olof Bengtsson, Charmain D. Hamilton, Christian Lydersen, Magnus Andersen \& Kit M. Kovacs \\ Norwegian Polar Institute, Fram Centre, Tromsø, Norway
}

\begin{abstract}
This study presents comprehensive mapping of the current distribution of pinnipeds and polar bears (Ursus maritimus) around Svalbard based on a regional marine mammal sightings programme and explores time-trends (2005-2018). Walruses (Odobenus rosmarus) were observed with high frequency and in high numbers around previously identified haul-out sites. At-sea walruses were seen close to the coast in shallow waters. Ringed seals (Pusa hispida) were observed in coastal areas throughout Svalbard, often in association with tidewater glacier fronts. There was no increase in the mean latitude for ringed seal observations, but there was an increased frequency of observations at around $82^{\circ} \mathrm{N}$, which reflects their following a northward shift in the ice edge during summer foraging trips. Bearded seals (Erignathus barbatus) were observed frequently in north-western Spitsbergen and shared many habitat features with ringed seals. There was a slight increase in the mean latitude of bearded seal observations and a decreased frequency of observation in the southern parts of the archipelago, suggesting that this species might be shifting its distribution. Harbour seal (Phoca vitulina) observations within fjords have increased, likely as a consequence of increased inflow of Atlantic water into west coast fjords. Harp seals (Pagophilus groenlandicus) were observed with high frequency north of Svalbard. Hooded seals (Cystophora cristata) were observed only rarely. Polar bears were reported most frequently, undoubtedly as a result of an effort bias favouring this species. In spite of biases, citizen-based observations are useful for assessing broad distributional patterns of marine mammals through time.
\end{abstract}

To access the supplementary material, please visit the article landing page

\section{Keywords}

Arctic, climate change, Erignathus barbatus, Pusa hispida, range shifts, Ursus maritimus

\section{Correspondence}

Kit M. Kovacs, Norwegian Polar Institute, Fram Centre, PO Box 6606 Langnes, NO-9296 Tromsø, Norway. E-mail: kit. kovacs@npolar.no

\section{Abbreviations \\ IMR: Institute of Marine Research, Norway KDE: kernel density estimation MMSDB: Marine Mammals Sightings Database \\ MODIS: moderate resolution imaging spectroradiometer (satellite instrument) NPI: Norwegian Polar Institute SST: sea-surface temperature}

\section{Introduction}

The Arctic is one of the regions of the globe where the impacts of climate change are being seen most indisputably (IPCC 2014; Pörtner et al. 2019). Global warming has led to increased air and water temperatures, reduction of sea ice and melting of glaciers, among other physical changes to the environment (Maslanik et al. 2007; Spielhagen et al. 201 1; Nuth et al. 2013; Serreze \& Stroeve 2015). These changes have been especially pronounced in the Barents Sea area, which is directly influenced by the inflow of warm (mixed) Atlantic Water from the south (Tverberg et al. 2014; Laidre et al. 2015; Lind et al. 2018). Since the beginning of the 2000s, the West
Spitsbergen Current, which runs along the continental shelf break west of the High-Arctic Svalbard Archipelago, has warmed markedly (Spielhagen et al. 2011). As a result, the marine ecosystem around Svalbard is being affected quite dramatically, giving rise to concern for Arctic species in the region (Kovacs et al. 2011 ; Fossheim et al. 2015; Descamps et al. 2017). There is therefore a need to study and monitor species distributions in order to document climate change impacts and to provide useful data for management bodies involved in spatial planning and protective measures (e.g., Laidre et al. 2015).

All of the North Atlantic Arctic pinnipeds are found in and around Svalbard, including year-round resident ringed seals (Pusa hispida), bearded seals (Erignathus barbatus) and 
walruses (Odobenus rosmarus), as well as seasonally-resident harp seals (Pagophilus groenlandicus) and hooded seals (Cystophora cristata) (Smith \& Lydersen 1991; Gjertz et al. 2000a, b; Kovacs et al. 2014). Additionally, there is a resident population of harbour seals (Phoca vitulina), which is the northernmost population of this wide-ranging, but largely north-temperate, species in the world (Merkel et al. 2013; Blanchet et al. 2014; Hamilton et al. 2014). Polar bears (Ursus maritimus) also range throughout the Svalbard Archipelago (Mauritzen et al. 2002; Aars et al. 2017; Lone et al. 2018). All of these marine mammals are high-trophic predators. The pinnipeds feed on a wide variety of fish and invertebrate species (Lydersen et al. 1989; Lydersen et al. 1991; Andersen et al. 2004; Skoglund et al. 2010). Pinnipeds themselves are prey for polar bears as well as Greenland sharks (Somniosus microcephalus) and Arctic foxes (Vulpes lagopus) (Lydersen \& Gjertz 1986; Derocher et al. 2002; Leclerc et al. 2012).

Ringed seals have a close association with ice and occupy fjord habitats as well as offshore drift-ice areas (Gjertz et al. 2000a; Wathne et al. 2000; Hamilton, Lydersen et al. 2015; Hamilton et al. 2016). Bearded seals are also found within fjords, generally occupying shallow areas (Hamilton et al. 2018, 2019). Walruses concentrate in shallow areas in summer periods when they haul out on land but spend time offshore in drift-ice during winter (Gjertz, Griffiths et al. 2001; Hamilton, Kovacs et al. 2015). The harbour seal population in Svalbard is concentrated around Prins Karls Forland, west of Spitsbergen (Gjertz, Lydersen et al. 2001; Blanchet et al. 2014; Hamilton et al. 2014). This species avoids heavy concentrations of sea ice, uses land as a haul-out platform and feeds in relatively shallow coastal waters, preferring the shelf edge west of Spitsbergen for foraging (Blanchet et al. 2014). Harp seals and hooded seals in the Barents Sea spend most of their time in drifting pack-ice areas and migrate seasonally to breed in the Greenland Sea or in the White Sea (Haug et al. 1994; Folkow \& Blix 1999; Folkow et al. 2004). Polar bears are also highly dependent on sea ice as a hunting ground and seem to prefer first-year ice, over the continental shelf or in coastal areas (Larsen 1986; Durner et al. 2009; Lone et al. 2018). Sea ice is particularly important to female bears as a transport corridor for travelling from the drifting pack ice to the denning areas on land, and for moving between areas with small cubs (Stirling $\delta$ Derocher 2012). The sea-ice dependence of all of these Arctic marine mammals makes them acutely susceptible to the negative impacts of climate change on their primary habitat. The situation for harbour seal is in marked contrast because the Svalbard Archipelago is likely to become a more suitable habitat for this species (Blanchet et al. 2014).
All of the pinnipeds that reside in, or frequent Svalbard waters, as well as the polar bear, have been the subjects of tracking studies, which provide considerable insight into their distributional ecology and habitat needs (Blanchet et al. 2014; Hamilton, Lydersen et al. 2015; Lowther et al. 2015; Hamilton et al. 2016; Hamilton et al. 2018, 2019; Lone et al. 2018). However, the specific sites where animals are captured does create geographical biases in area use and environmental conditions within the archipelago are changing very rapidly. Using citizen science in the form of extensive observations made throughout most of the Svalbard Archipelago over a period of close to two decades, provides a complementary large-scale data set for mapping species distributions and changes in them over time. It is also a good way to engage the public and to raise awareness and interest in climate change impacts on nature (Silvertown 2009; VannSander et al. 2016). Storrie et al. (2018) used the NPI's MMSDB to analyse the distribution and habitat characteristics of cetaceans around Svalbard during the period 2002-2014. The study contributed the first comprehensive baseline description of cetacean assemblages in Svalbard and documented signs of northward range expansions for many species (Storrie et al. 2018). The purpose of the current study was to conduct similar analyses for seals and polar bears in order to (1) increase knowledge of the distributions of pinnipeds and polar bears around Svalbard, (2) to analyse habitat characteristics for the various species to increase predictive capacity for assessment of climate change impacts and (3) detect potential distributional shifts over time-using the MMSDB records for pinnipeds and bears.

\section{Materials and methods}

Observations of marine mammals in Svalbard have been collected since 2002; they are stored in the MMSDB (https://data.npolar.no/sighting/), managed by the NPI. Observations of marine mammal species are recorded with date and coordinates, along with some information about species, number of individuals in a group, maturity status or other things of note regarding behaviour, body condition etc., as well as the name of the reporting vessel and a contact person. Marine Cruise Expedition operators, the Norwegian Coast Guard, personnel on research expeditions (e.g., NPI and IMR), local residents and the Governor of Svalbard's field inspectors all report sightings to the MMSDB. The reporting area is Svalbard fjords and surrounding waters, $74-84^{\circ} \mathrm{N}$ and $0-35^{\circ} \mathrm{E}$ (Fig. 1). For this study, the period 2005-2018 was selected because these years offered sufficient sample sizes; in the early years of MMSDB (2002-04), records were limited. 


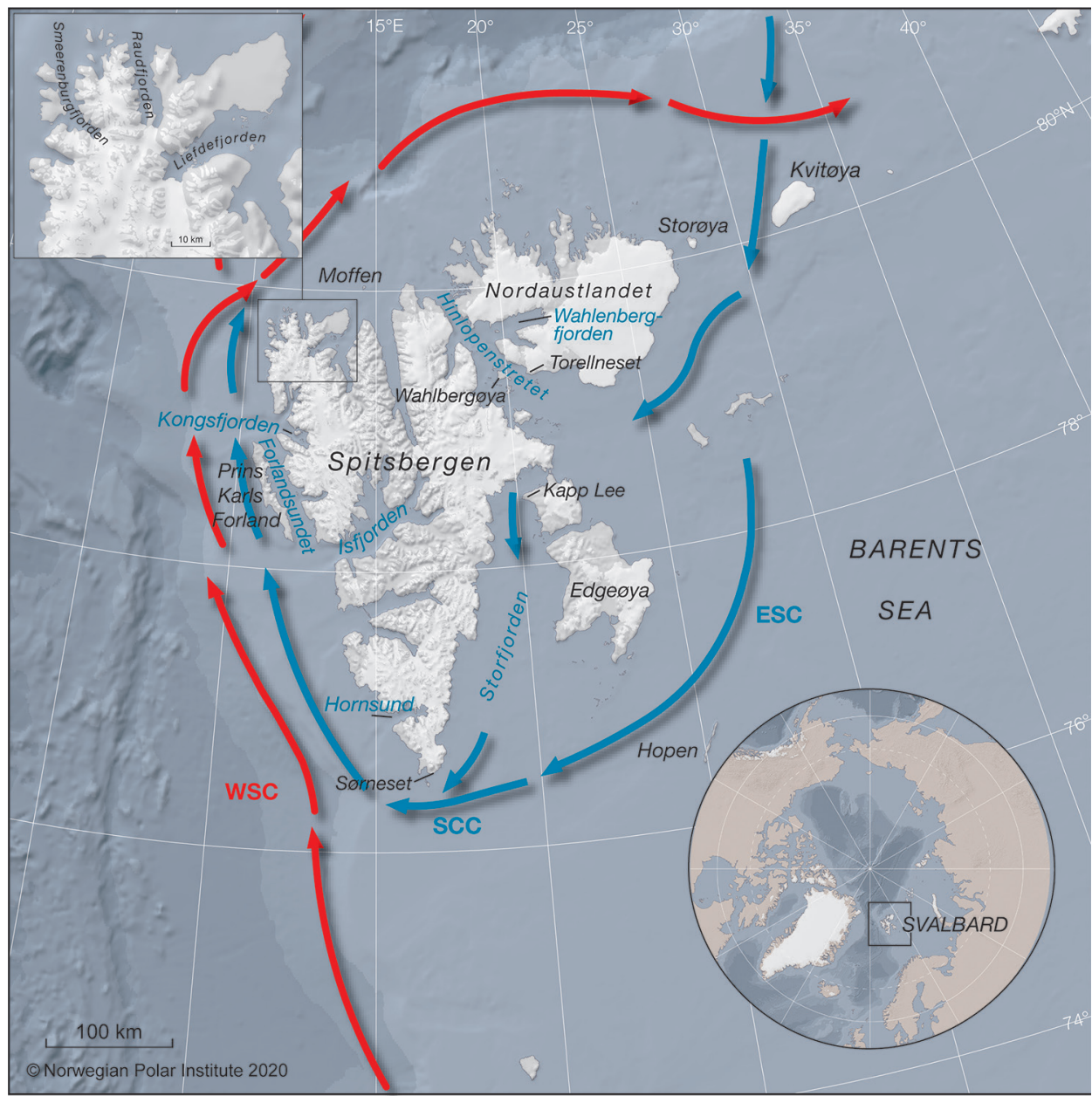

Figure 1 Map of the study region, showing names of places mentioned in the text. Arrows show ocean currents present around Svalbard; WSC: West Spitsbergen Current; ESC: East Spitsbergen Current; SCC: South Cape Current. Red arrows represent currents of Atlantic Water and blue arrows represent Arctic Water.

\section{Environmental variables}

In order to characterise habitats used by the study species, environmental variables were extracted from grid files for each observation, based on the coordinates of the observations, using the raster package in $\mathrm{R}$ version 3.5.2 ( $\mathrm{R}$ Development Core Team 2018). Monthly daytime SST at $11 \mu \mathrm{m}$ wavelength, with a 4-km resolution, was acquired from the MODIS system (NASA 2014). SSTs were assigned to each observation using a $12-\mathrm{km}$ radius buffer (calculating the mean temperature even when observations had coordinates on land, that is, animals hauled out). The buffer radius was gradually increased to $130 \mathrm{~km}$ for observations where the original buffer was too small to assign a value, as in the case of animals observed deep in pack ice. In such cases, an SST of $0^{\circ} \mathrm{C}$ was assigned to reflect the SST of water in proximity to sea ice. Sea-ice charts, produced by the Ice Service of the Norwegian Meteorological Institute (http://osisaf.met.no/p/ice/index.html) were used to acquire data on daily sea ice coverage. These charts categorise sea-ice coverage in the following categories: $0 \%$, $0-10 \%, 10-40 \%, 40-70 \%, 70-90 \%, 90-100 \%$ and $100 \%$. Bathymetry values were acquired from the International Bathymetric Chart of the Arctic Ocean version 3.0 (Jakobsson et al. 2012). Because of the resolution of this chart $(500 \mathrm{~m} \times 500 \mathrm{~m})$, depth was divided into categories of $<5 \mathrm{~m}, 5-25 \mathrm{~m}, 25-50 \mathrm{~m}, 50-100 \mathrm{~m}, 100-200 \mathrm{~m}$ and $>200 \mathrm{~m}$. Distance from the coast and distance from tidewater glacier fronts was calculated using the 'rgeos' package in $\mathrm{R}$ together with polygon shape-files of the Svalbard Archipelago and tidewater glacier fronts (Kohler et al. 2018).

\section{Data analysis}

KDEs for each species were calculated with the 'ks' package in $\mathrm{R}$, using a normal scale bandwidth selector and a grid size of $1 \mathrm{~km}$, displayed with 10 quantiles 
(Silverman 1986; Chacón \& Duong 2018). Following Storrie et al. (2018), temporal changes of observation frequencies were visualised by taking KDEs for the first half of the study period (2005-2011) and subtracting them from KDEs calculated for the most recent half of the study period (2012-18). A land polygon for the Svalbard Archipelago was plotted on top of the kernels for visual representation of KDEs, since the ' $\mathrm{kde}^{\prime}$ function in the ' $\mathrm{ks}$ ' package in $\mathrm{R}$ does not discriminate between land and sea. This results in masking of observations inland, but given the coastal distribution of the study species and the coastal nature of the observations reported to the MMSDB, this is a minor concern; only bears walk across land/glaciers and the coastal observation platforms would rarely see these animals if they were more than $1 \mathrm{~km}$ inland in any case. To explore potential trends with regard to latitudinal changes over time, linear regressions of yearly mean latitude were calculated for each species. Level of significance was set at $\alpha=0.05$.

\section{Results}

A total of 127573 individual animals, derived from 6985 observations of pinnipeds and 4002 observations of polar bears (involving 7248 individual polar bears) were recorded in the MMSDB during the study period (Table 1). Most of the observations $(9333 ; 85 \%)$ were made during the summer months (June-August), while 14\% were during the months when there was a mix of light and dark. Ninety-one $(0.8 \%)$ observations were reported during the polar night (November-February): 52 (57\%) were of polar bears; 16 (18\%) were of walruses; and 10 ( $11 \%$ ) were of bearded seals.

The polar bear was the most frequently reported species, followed by the walrus (Table 1; Fig. 2a). The walrus was the species with the greatest number of individuals
(75 416), followed by the harp seal (32 783; Table 1; Fig. 2b). Most observations were of single animals. However, both harp seals and walruses had median group sizes of six and were on a few occasions observed in larger groups of 1000 animals or more (Table 1).

\section{Resident pinnipeds}

Walruses. Walrus observations occurred most frequently around the north-west corner of Spitsbergen, in Forlandsundet and in the area between Torellneset and Wahlbergøya on Nordaustlandet, in the north-east of the archipelago (Fig. 3a). In terms of the number of animals, most individuals were observed around Moffen, Storøya and Torellneset (Fig. 3b). Walrus observations were recorded in areas with relatively shallow water; $57 \%$ of the observations were from areas with a depth of less than $5 \mathrm{~m}$ (this includes animals on shore) and only $8 \%$ of the observations were from areas with a depth $>100 \mathrm{~m}$ (Fig. $4 a)$. Walruses were generally observed in areas with little or no sea ice $(53 \%) ; 9 \%$ of the observations of this species were from areas with $\geq 40 \%$ ice cover (Fig. $4 \mathrm{~b}$ ). Walruses were generally observed close to the coast (median $=0.3$ $\mathrm{km}$; Fig. 4c), but not close to tidewater glacier fronts (median $=17 \mathrm{~km}$; Fig. $4 \mathrm{~d}$ ). The median SST in the areas in which they were observed was $2.9^{\circ} \mathrm{C}$ (Fig. 4e).

Ringed seals. Ringed seals were observed most frequently in north-western Spitsbergen but were seen in coastal areas throughout the archipelago and in areas with drifting ice north of Spitsbergen (Fig. 5a). In terms of number of animals, frequencies were high in Isfjorden, Hornsund and Wahlenbergfjorden (Fig. 5b). Ringed seals were generally observed close to land in relatively shallow areas. The median distance from the coastline was $1.2 \mathrm{~km}$ (Fig. 4c) and $45 \%$ of the observations were from areas with a depth of $<5 \mathrm{~m}$. An additional $31 \%$ of the observations of

Table 1 Number of observations and number of individuals, median group size and the largest recorded group size for pinniped species and polar bears in the MMSDB for the years 2005-2018; early (2005-2011) and late (2012-18) records are identified in parentheses.

\begin{tabular}{lccc}
\hline Species & $\begin{array}{c}\text { Number of observations } \\
\text { (Early period / late period) }\end{array}$ & $\begin{array}{c}\text { Total number of } \\
\text { individuals }\end{array}$ & Median group size \\
\hline Bearded seal & $1503(536 / 967)$ & 3969 & 1 \\
Harbour seal & $513(97 / 416)$ & 4600 & 2 \\
Harp seal & $848(342 / 506)$ & 32783 & 6 \\
Hooded seal & $45(18 / 27)$ & 52 & 151 \\
Ringed seal & $764(312 / 452)$ & 5569 & 1 \\
Walrus & $2848(939 / 1909)$ & 75416 & 6 \\
Unidentified pinniped & $464(262 / 202)$ & 3184 & 1 \\
Polar bear & $4002(1433 / 2569)$ & 7248 & 1000 \\
\hline
\end{tabular}

a'Group' includes animals observed in the same area and does not necessarily refer to a social group. 
(a)

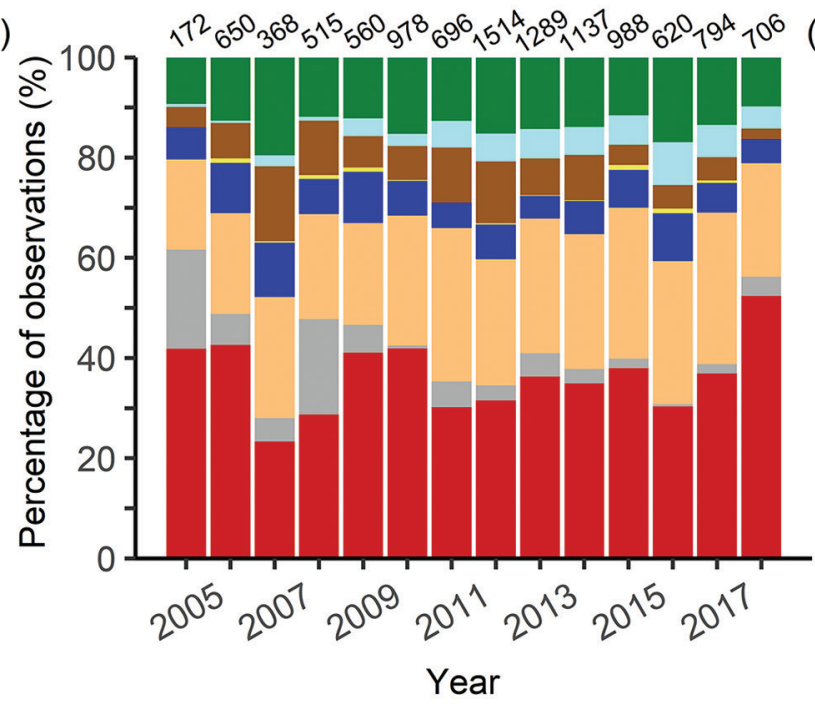

Bearded seal Harbour seal

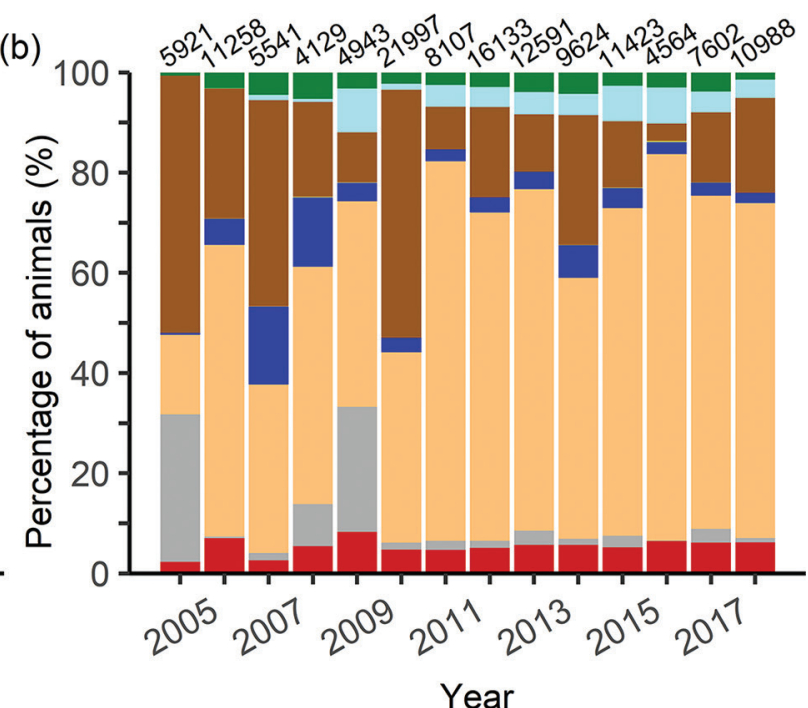

Ringed seal Walrus
Unidentified seal

Polar bear

Figure 2 (a) Yearly percentage of observations for different species of pinnipeds and the polar bear recorded in the MMSDB during 2005-2018. (b) Yearly percentage of animals for different species of pinnipeds and the polar bear recorded in the MMSDB during 2005-2018. Sample sizes for each year are given over the corresponding bars.

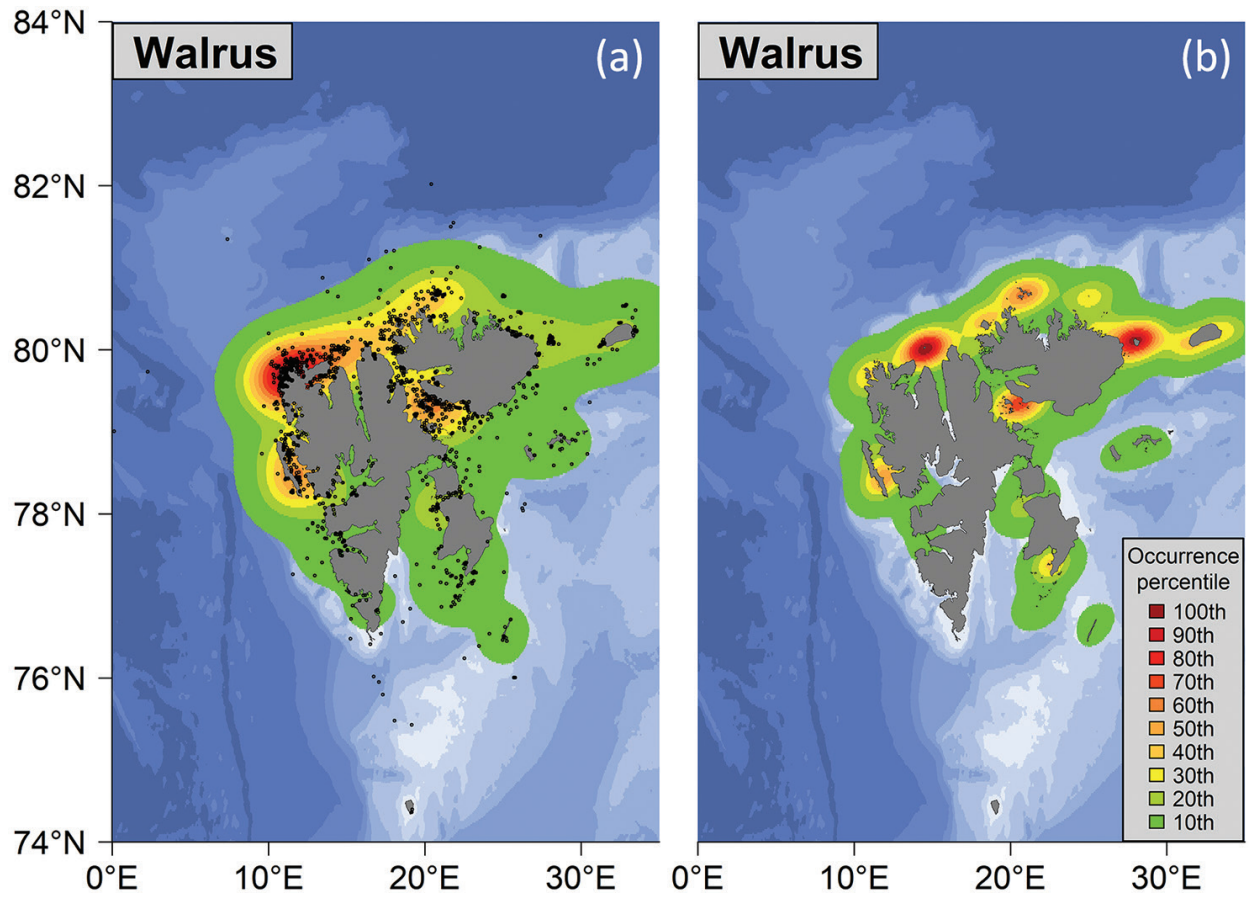

Figure 3 KDE plots showing observation frequencies of walruses around Svalbard during 2005-2018, based on (a) number of observations and (b) number of animals observed. Black circles mark locations of observations. 


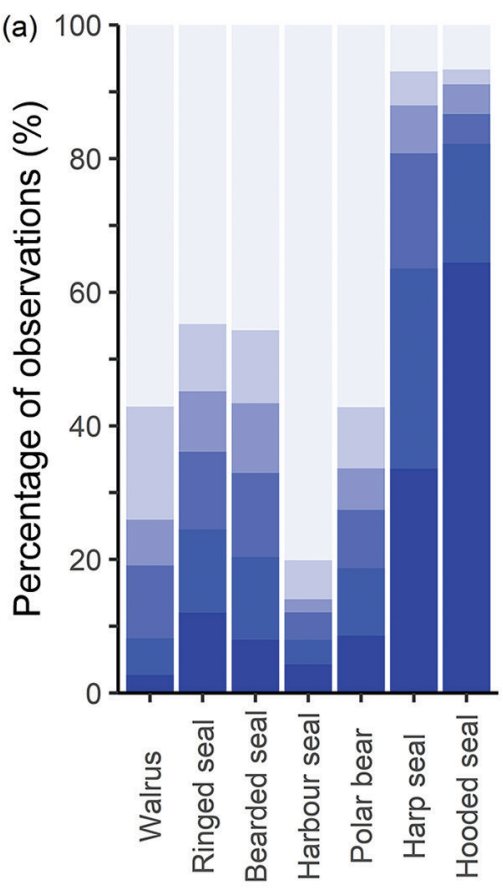

(c)

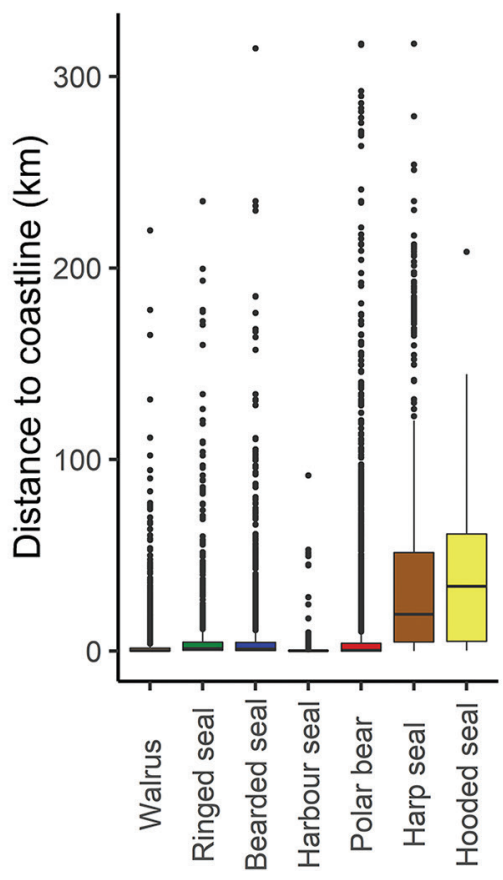

(d)

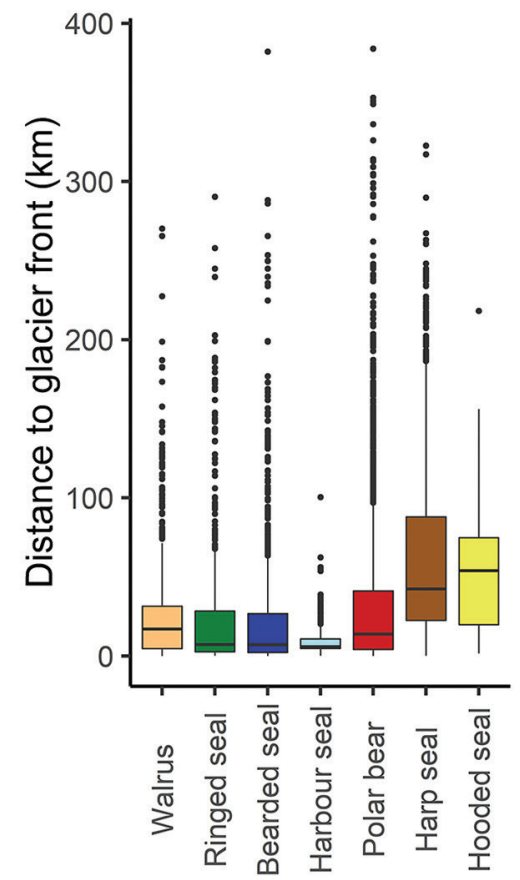

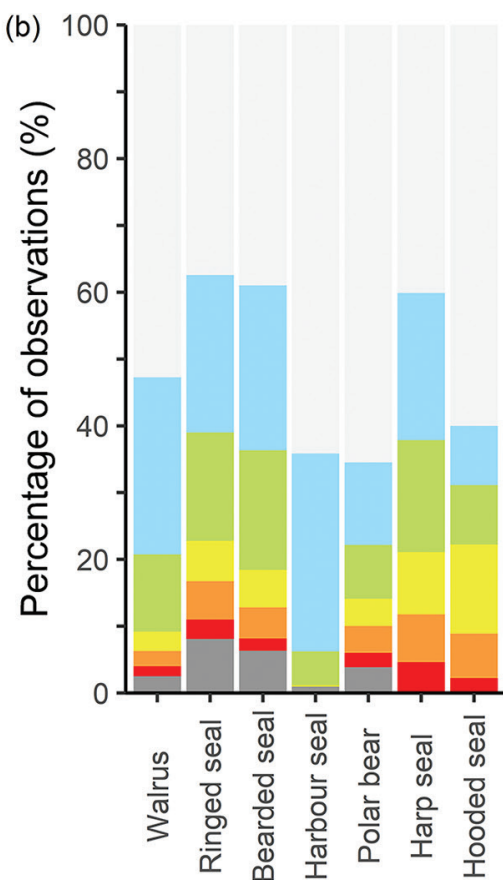

(e)

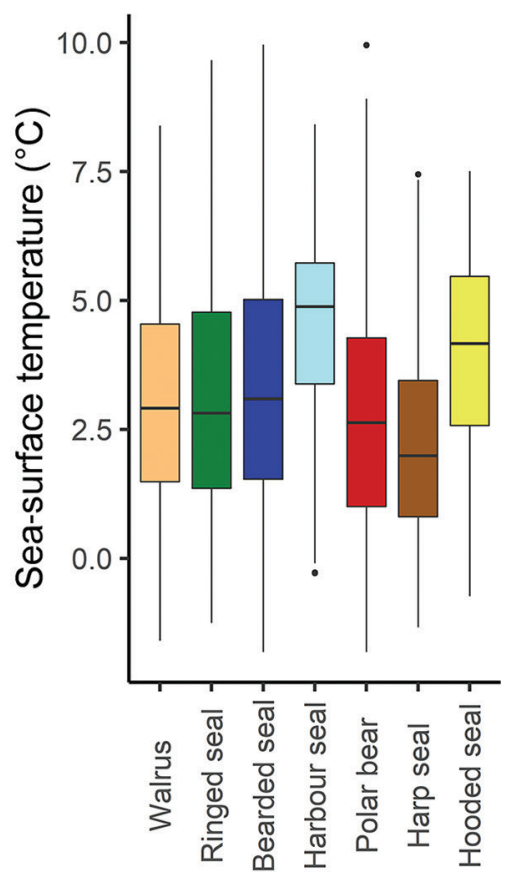

Figure 4 Environmental variables for observations of seven different species of marine mammals that were recorded in the MMSDB during $2005-2018$. (a) Depth, (b) ice cover, (c) distance to coastline, (d) distance to tidewater glacier front and (e) SST. Boxplots show values between the 25th and the 75th percentile within boxes that are divided by the median. Vertical lines outside the boxes extend to the maximum and the minimum values up to 1.5 times higher or lower than the upper and lower quartile. Dots represent outliers, more than 1.5 times higher or lower than the upper and lower quartile. 

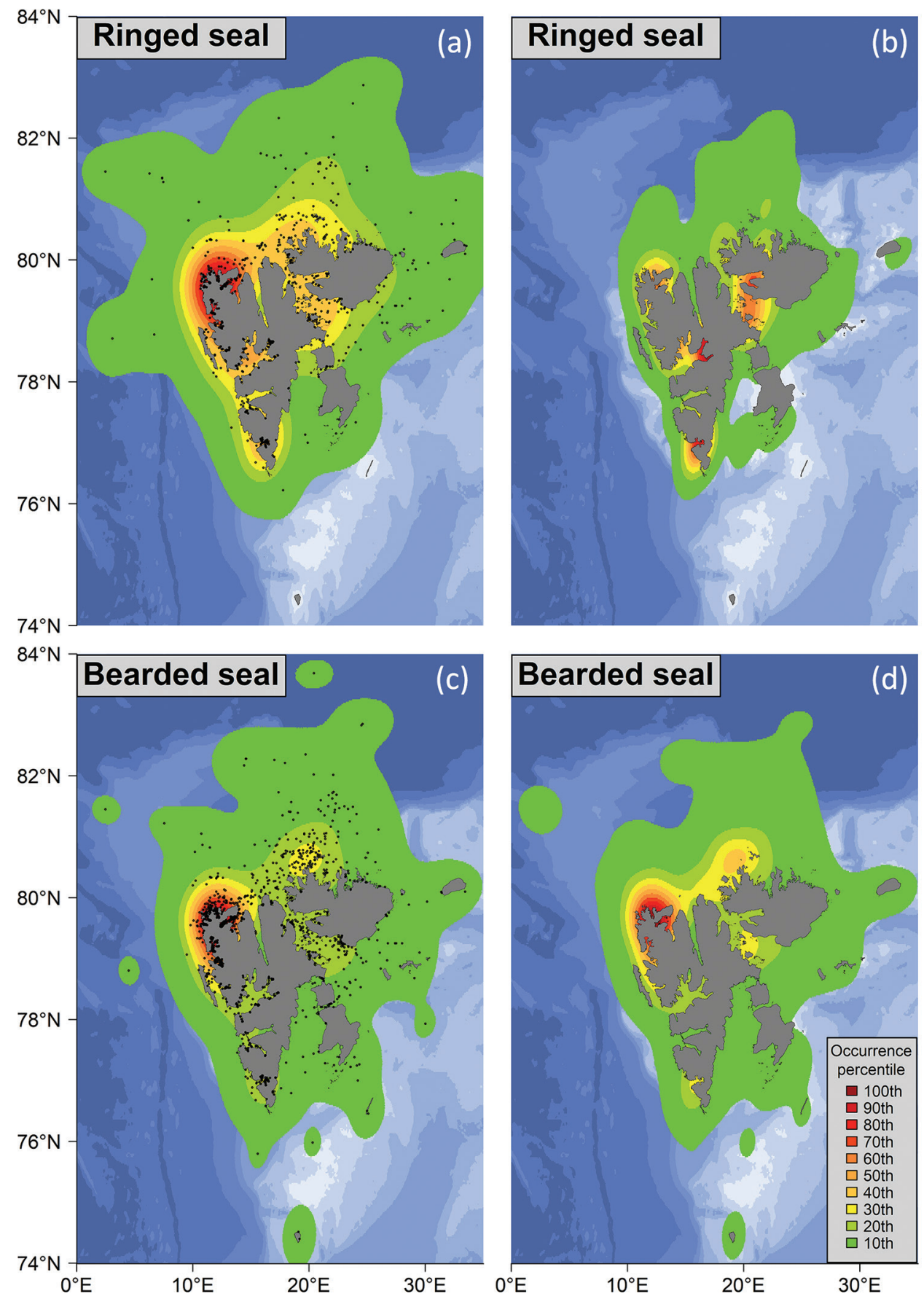

Figure 5 KDE plots showing observation frequencies of ringed seals and bearded seals around Svalbard during 2005-2018, based on (a) number of ringed seal observations and (b) number of ringed seals observed; (c) number of bearded seal observations and (d) number of bearded seals observed. Black circles mark locations of observations.

ringed seals were from areas with a depth between 5 and $100 \mathrm{~m}$ (Fig. 4a). Ringed seals were often seen in ice-filled waters, $17 \%$ of the observations were from areas with sea-ice concentration of $\geq 70 \%$ (Fig. $4 \mathrm{~b}$ ). In this high ice concentration category, $61 \%$ of the sightings involved seals hauled out on ice, $20 \%$ were in the water and the last 19\% lacked specific information regarding the activity of the seals. Ringed seals were often observed close to tidewater glacier fronts (median $=7.3 \mathrm{~km}$; Fig. $4 \mathrm{~d}$ ) and in areas with moderate SST $\left(2.8^{\circ} \mathrm{C}\right.$; Fig. $\left.4 \mathrm{e}\right)$. 
Bearded seals. Bearded seals were most commonly observed in the north-west corner of Svalbard (Fig. 5c, $\mathrm{d}$ ). They were usually close to the coast (median $=1.0$ km; Fig. 4c) in shallow areas; $46 \%$ of the bearded seal observations were from areas with a depth of $\leq 5 \mathrm{~m}$ and $34 \%$ of the observations for this species were in areas with a depth between 5 and $100 \mathrm{~m}$ (Fig. 4a). Similar to ringed seals, the bearded seal was commonly observed in areas with sea-ice concentrations $\geq 70 \%$ (13\%; Fig. $4 \mathrm{~b}$ ) and close to tidewater glacier fronts (median distance $=$ $7.1 \mathrm{~km}$; Fig. 4d) and the median SST for this species was $3.1^{\circ} \mathrm{C}$ (Fig. $\left.4 \mathrm{e}\right)$.

Harbour seals. Harbour seals were almost exclusively observed on the west coast of Spitsbergen, with the exception of one observation of a single animal in Wahlenbergfjorden and two observations of single animals on Edgeøya (Fig. 6a). The highest frequency of observations and the greatest numbers were seen in Smeerenburgfjorden (Fig. 6). Harbour seals were observed close to the coast (median $=0.2 \mathrm{~km}$; Fig. $4 \mathrm{c}$ ) and also modestly close to tidewater glacier fronts (median = $6.0 \mathrm{~km}$; Fig. 4d). They were the pinniped with the highest percentage of observations in shallow areas (including hauled out animals- $80 \%$ from 5 m or less; Fig. 4a) and the species with the highest percentage of observations in ice-free waters $(64 \%)$. Only $1 \%$ of the observations were from areas with $\geq 40 \%$ ice cover (Fig. 4b). Harbour seals were also the species that occurred in areas with the highest median SST $\left(4.9^{\circ} \mathrm{C}\right.$; Fig. $\left.4 \mathrm{e}\right)$.

Polar bears. Polar bears were seen most commonly in north-western Spitsbergen, around Raudfjorden, both in terms of number of observations and number of animals observed (Fig. 7). They were observed at a median distance of $0.4 \mathrm{~km}$ from the coast and were not tightly associated with tidewater glacier fronts (median distance 14 km; Fig. 4c, d). Polar bears were often seen in shallow areas with little ice cover or on land; $57 \%$ of the observations were from areas with a depth of $5 \mathrm{~m}$ or less (Fig. 4a) and $65 \%$ of the bear observations were from areas with $0 \%$ ice cover (Fig. $4 \mathrm{~b}$ ). The median SST in the areas where polar bears were observed was $2.6^{\circ} \mathrm{C}$ (Fig. $4 \mathrm{e}$ ).

\section{Seasonal visitors}

Harp seals. Harp seal observations were most frequent in northern Svalbard, especially in Liefdefjorden and areas around Moffen and at the sea-ice edge north of Svalbard (Fig. 8a). However, on account of one observation of a large group of 10000 harp seals, the highest frequency of observations in terms of number of animals was around $76^{\circ} \mathrm{N}$, off the southern tip of Spitsbergen (Fig. 8b). Harp seals were observed further away from the coastline than

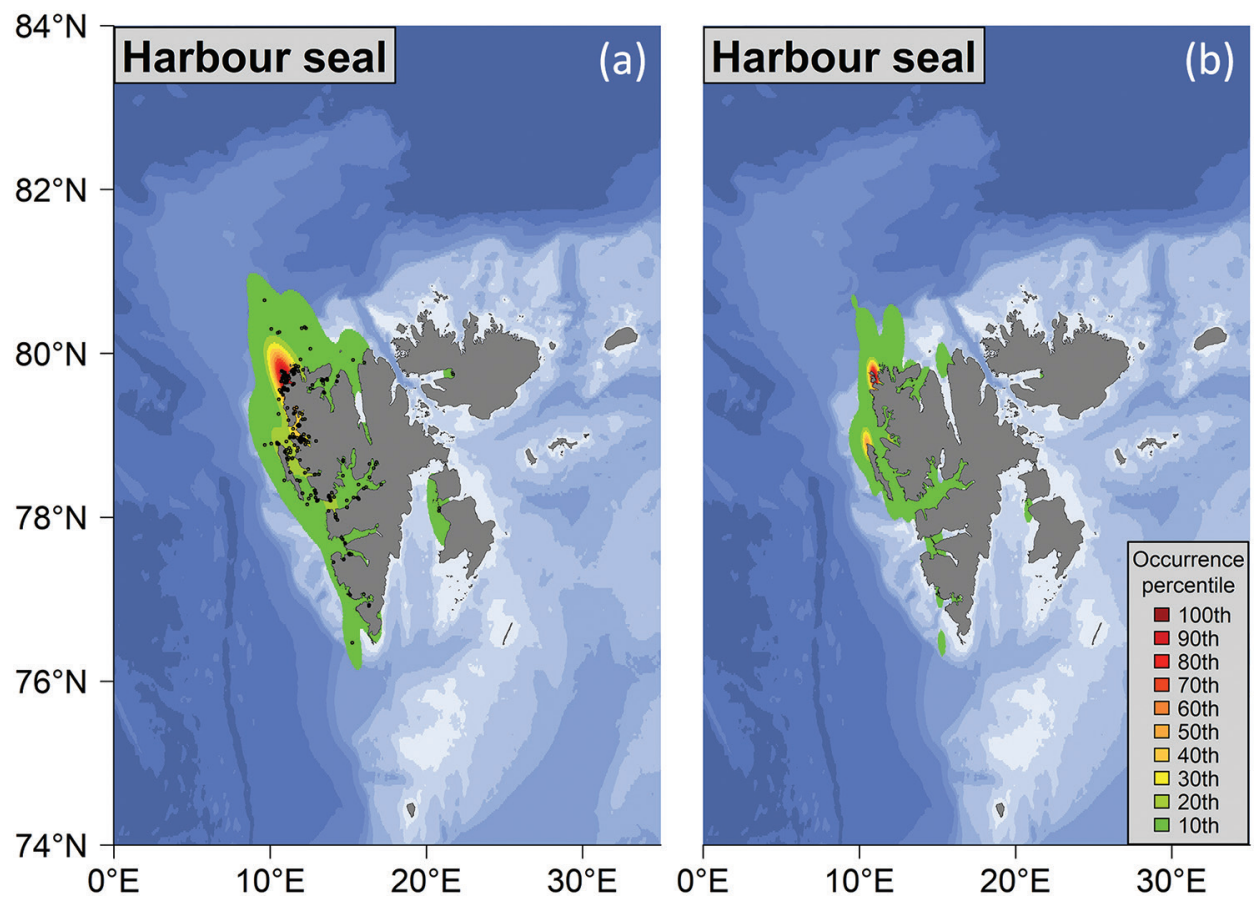

Figure 6 KDE plots showing observation frequencies of harbour seals around Svalbard during 2005-2018, based on (a) number of observations and (b) number of animals observed. Black circles mark locations of observations. 


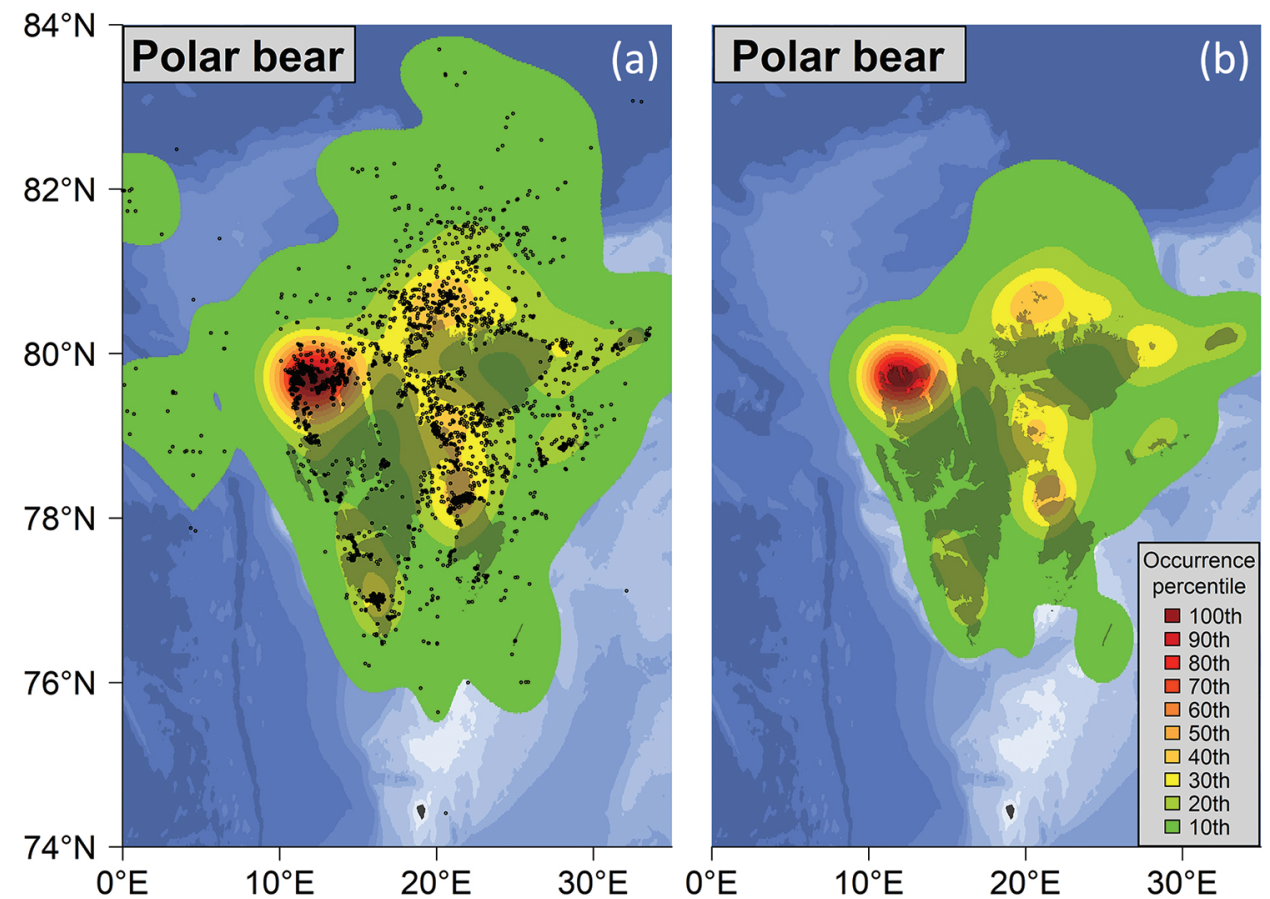

Figure 7 KDE plots showing observation frequencies of polar bears around Svalbard during 2005-2018, based on (a) number of observations and (b) number of animals observed. Black circles mark locations of observations.

the resident species (median $=19 \mathrm{~km}$; Fig. 4c) and far from tidewater glacier fronts (median $=42 \mathrm{~km}$; Fig. $4 \mathrm{~d}$ ). They were observed in deep water; $64 \%$ of the observations were from areas $\geq 100 \mathrm{~m}$ and $34 \%$ were from areas $\geq 200 \mathrm{~m}$ (Fig. 4a). SSTs where harp seals were observed were cold $\left(\right.$ median $=2.0^{\circ} \mathrm{C}$; Fig. $4 \mathrm{e}$ ), but ice concentrations were generally light, with $60 \%$ of observation in areas with $\leq 10 \%$ ice cover and only $10 \%$ of observations in areas with $\geq 70 \%$ ice cover (Fig. $4 b$ ).

Hooded seals. Hooded seals were the least commonly sighted pinniped ( $N=45$; Table 1$)$. The observation frequency, both in terms of observations and number of animals, was highest along the west coast of Spitsbergen, especially around the north-west corner (Fig. 8c, d). They were found in deep water; $64 \%$ of the observations were from areas with depths $\geq 200 \mathrm{~m}$ (Fig. 4a). Hooded seals were observed far from the coast (median $=34 \mathrm{~km}$; Fig. $4 \mathrm{c}$ ) and tidewater glacier fronts (median $=54 \mathrm{~km}$; Fig. $4 \mathrm{~d}$ ). They were observed in waters with relatively high SSTs (median $=4.2^{\circ} \mathrm{C}$; Fig. $4 \mathrm{e}$ ) and little ice cover; $60 \%$ of the observations were from areas with no sea ice (Fig. $4 \mathrm{~b}$ ).

\section{Temporal changes: resident species}

There was no significant increase in mean latitude for walruses (Supplementary Fig. S1); 0.5\% of the observations were made north of $81^{\circ} \mathrm{N}$ during the recent period and only $0.1 \%$ during the early period. Frequencies of walrus observations increased in the north-west corner of Spitsbergen and in Forlandsundet over the study period (Fig. 9a), while they decreased slightly at the north end of Hinlopenstretet, between Spitsbergen and Nordaustlandet, and also close to the Kapp Lee haul-out site (Fig. 9a).

There was no significant increase in the mean latitude of ringed seal observations (Supplementary Fig. S2), but $7 \%$ of the observations were made north of $81^{\circ} \mathrm{N}$ during the recent period, compared to $2 \%$ during the early period. Ringed seals were reported more frequently in the central regions of Spitsbergen during the recent period, especially in the inner parts of Isfjorden (Fig. 9b). Decreases were seen immediately north of Spitsbergen, in Hornsund and other parts of southern Spitsbergen (Fig. 9b).

There was a significant increase in the mean latitude at which bearded seals were observed during the study period $\left(0.03^{\circ}\right.$ per year; $p=0.045$, d.f. $=12$; Fig. $\left.10 \mathrm{a}\right)$. The greatest increases in the frequency of bearded seal observations from the early to the recent period were seen in the coastal regions in the north-west and the easternmost parts of Spitsbergen (Fig. 9c). There was also an increase between $81^{\circ} \mathrm{N}$ and $82^{\circ} \mathrm{N}$, north of Nordaustlandet at around $20^{\circ} \mathrm{E}$ (Fig. 9c). During the recent period, $5 \%$ of the observations were observed north of $81^{\circ} \mathrm{N}$, whereas during the early period the proportion of observations 

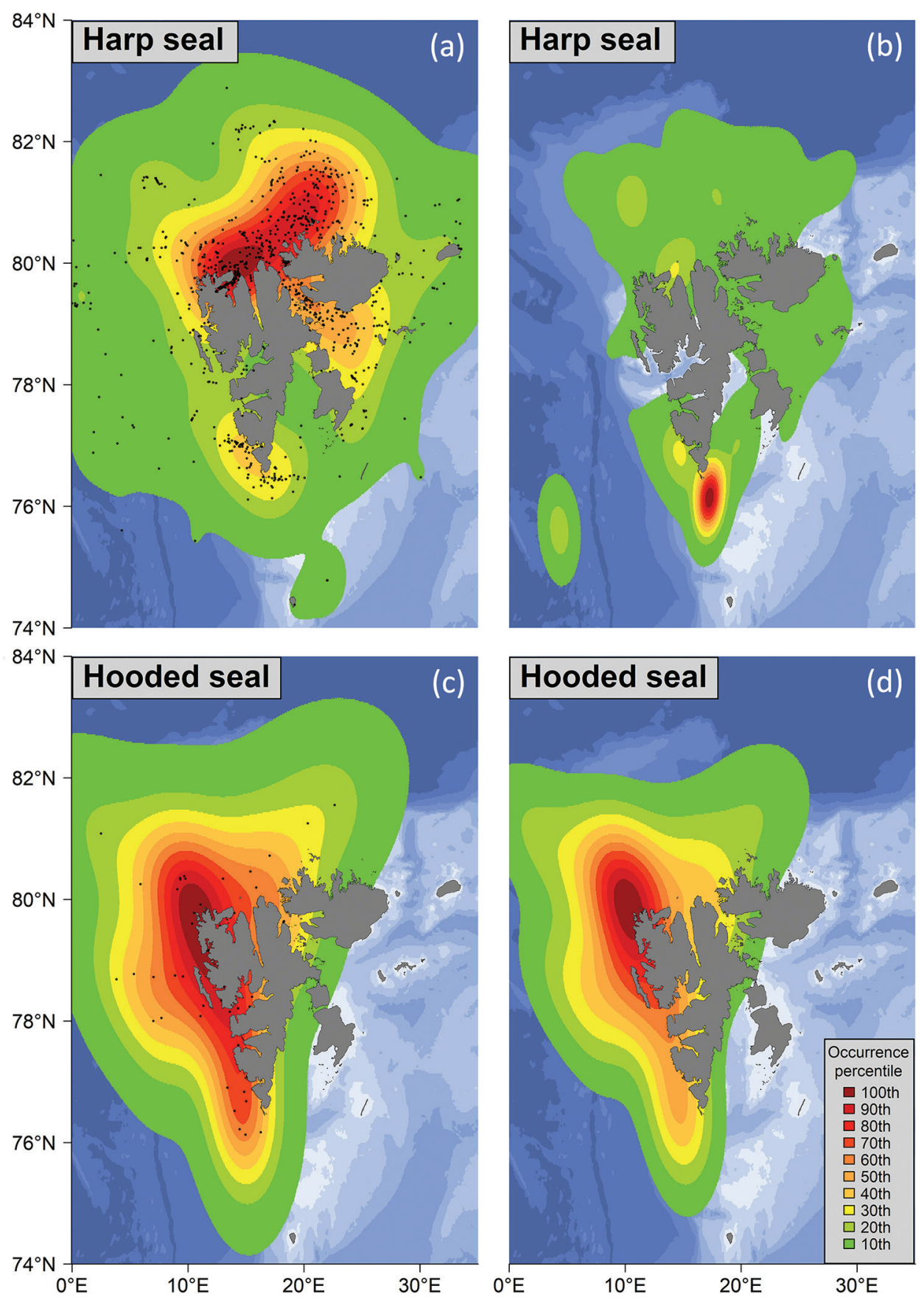

Figure 8 KDE plots showing observation frequencies of harp seals and hooded seals around Svalbard during 2005-2018, based on (a) number of harp seal observations and (b) number of harp seals observed; (c) number of hooded seal observations and (d) number of hooded seals observed. Black circles mark locations of observations.

this far north was $2 \%$. Decreases in the frequency of sightings were seen in southern Svalbard, especially in Hornsund (Fig. 9c).

There was no significant trend in the mean latitude for harbour seal observations during the study period (Fig. $10 \mathrm{~b}$ ) although latitude accounted for approximately $20 \%$ of the variance in location through time. Harbour seals were observed more often in the north-westernmost fjords on Spitsbergen, while there was a decrease in sightings at the north end of Prins Karls Forland (Fig. 9d).

There was a significant increase in mean latitude at which polar bears were observed during the study period 

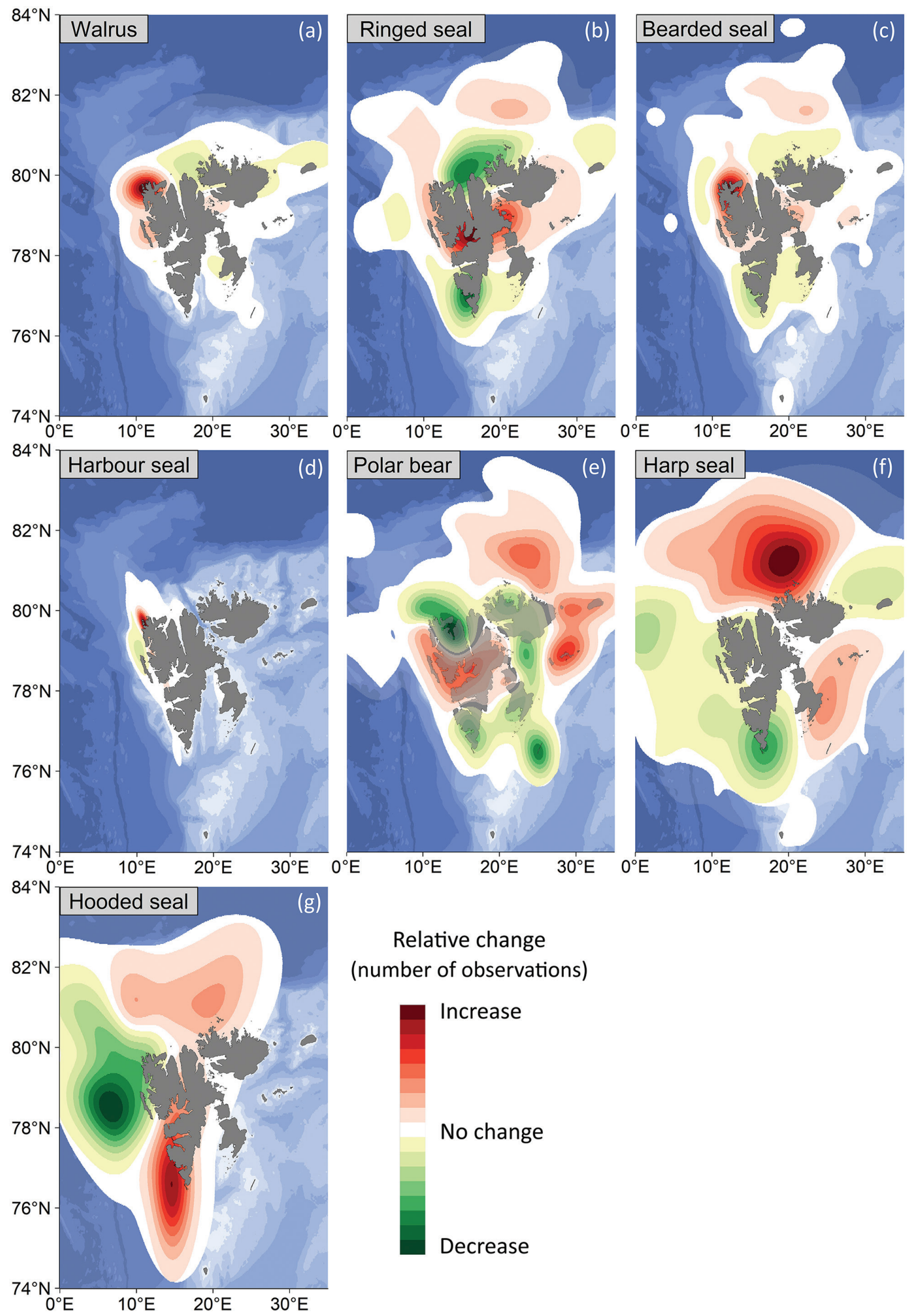

\section{Relative change (number of observations)}

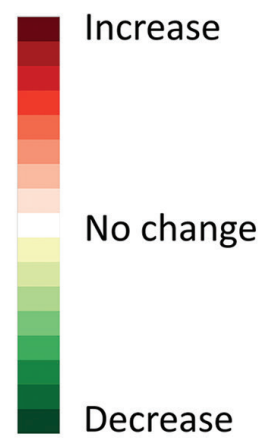

Figure 9 KDE plots showing change in observation frequency around Svalbard between the early period (2005-2011) and the late period (2012-18) for (a) walruses, (b) ringed seals, (c) bearded seals, (d) harbour seals, (e) polar bears, (f) harp seals and (g) hooded seals. 
(a)

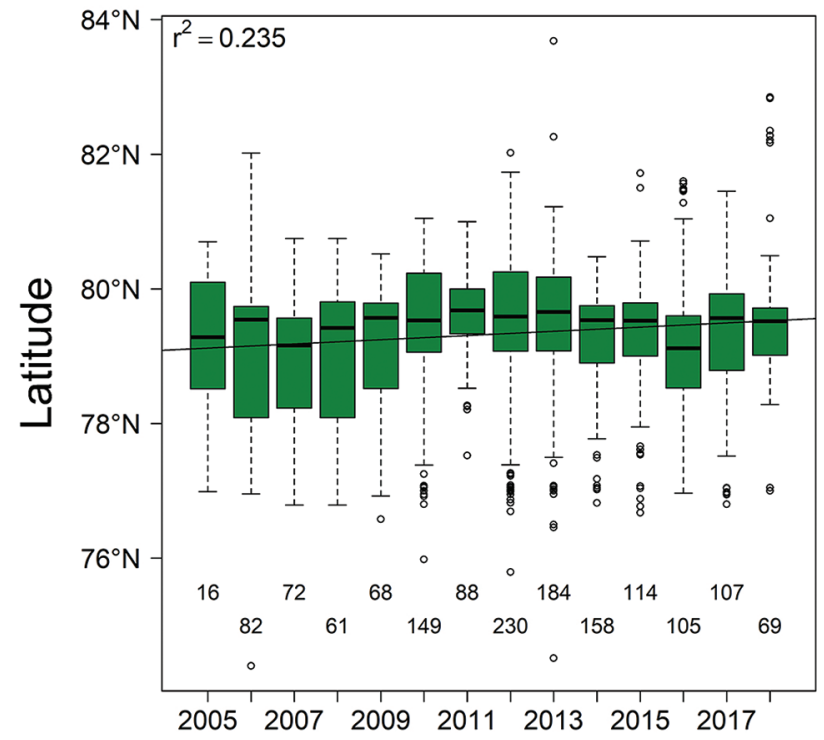

(c)

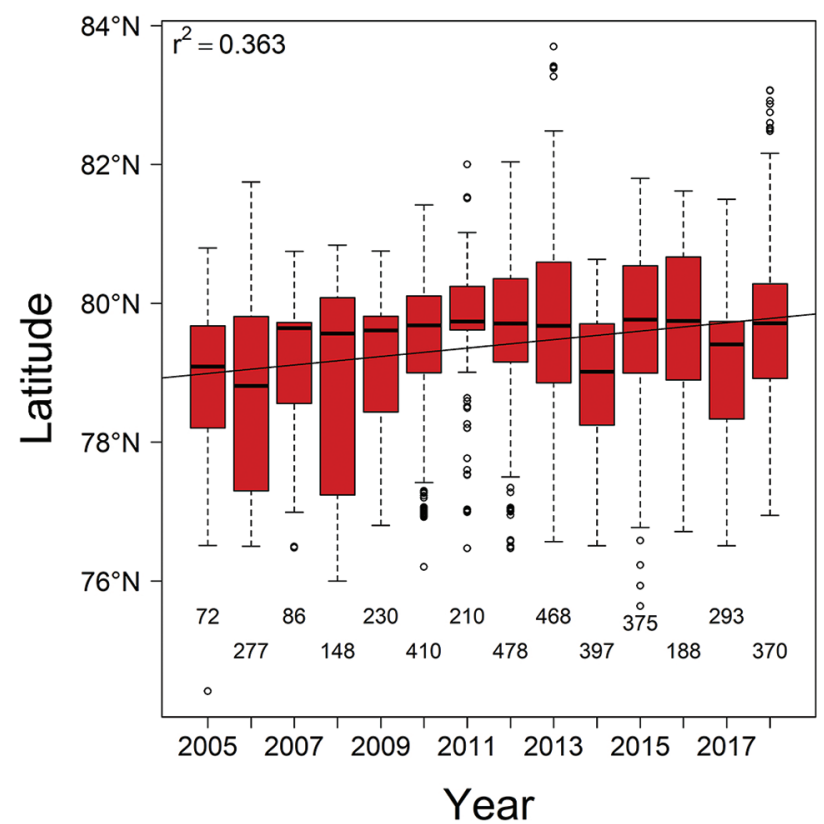

(b) Harbour seal

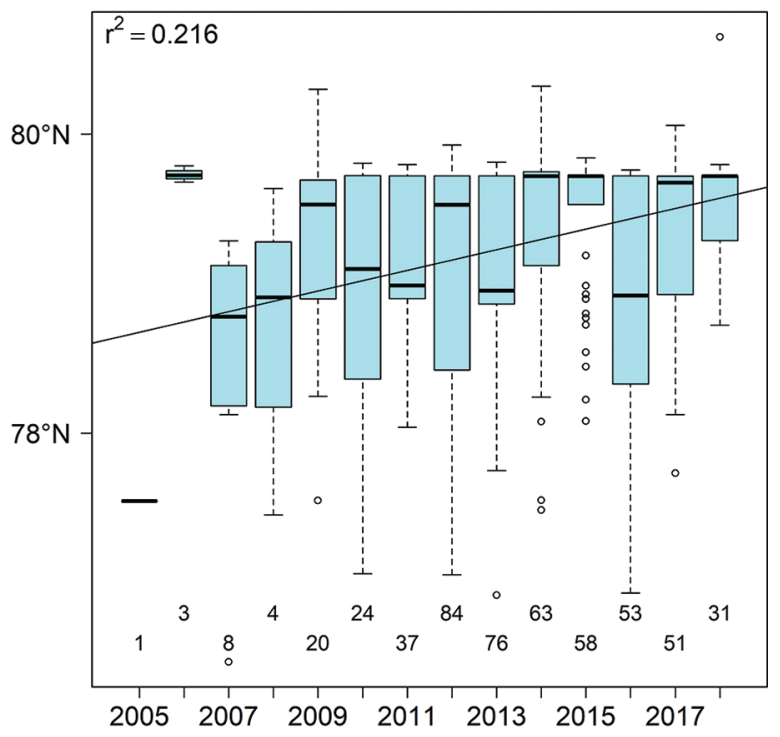

(d)

Harp seal

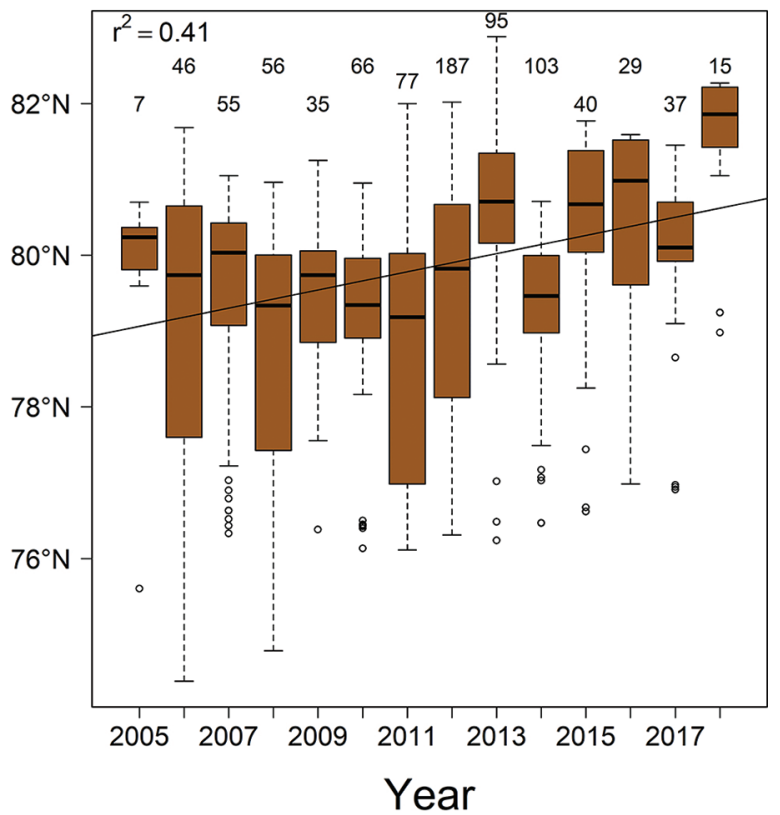

Figure 10 Latitude of observations for four different species in the MMSDB recorded during 2005-2018; showing (a) bearded seals, (b) harbour seals, (c) polar bears and (d) harp seals. Boxplots show values between the 25th and the 75th percentile within boxes that are divided by the median. Vertical lines outside the boxes extend to the maximum and the minimum values up to 1.5 times higher or lower than the upper and lower quartile. Circles represent outliers, more than 1.5 times higher or lower than the upper and lower quartile. Linear regression of the mean for each year is displayed as a black line together with the $r^{2}$ value for the regression in the top left corner. Numbers above or below error bars depict sample sizes. 
$\left(0.06^{\circ}\right.$ per year; $p=0.013$, d.f. $=12$; Fig. $\left.10 \mathrm{c}\right)$. The proportions of observations made north of $81^{\circ} \mathrm{N}$ were $9 \%$ during the recent period and $2 \%$ during the early period. The observation frequency of polar bears increased in the central parts of Spitsbergen, especially in Isfjorden and on Prins Karls Forland (Fig. 9e). There were also increases in areas in the north, east and south-east of Nordaustlandet (Fig. 9e). Decreases were seen in north-central and southern Spitsbergen and in the vicinity of Hopen (Fig. 9e).

\section{Temporal changes: seasonal visitors}

There was a significant increase in the mean latitude at which harp seals were observed during the study period $\left(0.12^{\circ}\right.$ per year; $p=0.0081$, d.f. $=12$; Fig $\left.10 \mathrm{~d}\right)$. Observation frequency increased north of Svalbard during the recent period compared to the early period ( $24 \%$ of observations compared to $6 \%$ of observations), especially at around $81^{\circ} \mathrm{N}$, off the coast of Nordaustlandet (Fig. 9f).

There was no significant latitudinal shift for hooded seals observations (Supplementary Fig. S3). The observation frequency of hooded seals increased off the coast of south Spitsbergen, at around $77^{\circ} \mathrm{N}$ and $15^{\circ} \mathrm{E}$ and north of Svalbard around $81^{\circ} \mathrm{N}$ and between $10^{\circ} \mathrm{E}$ and $22^{\circ} \mathrm{E}$, while it decreased in eastern Svalbard at around $79^{\circ} \mathrm{N}$ and $8^{\circ} \mathrm{E}$ (Fig. 9g).

\section{Discussion}

This study was based on data that was largely acquired via 'citizen science'. Using the MMSDB made it possible to map the spatial and temporal distribution of pinnipeds and polar bears in Svalbard during an extended period, throughout much of the Svalbard Archipelago and compare trends in distribution over time. This study joins a growing list of successful applications of this type of data to monitoring distribution and habitat use of marine mammal populations across the world (Tonachella et al. 2012; Lodi \& Tardin 2018; Storrie et al. 2018; LaRue et al. 2020; Stephenson et al. 2020). However, using data acquired by citizen science does mean accepting some biases. For example, there are no real measures of sighting effort though the routes taken by the reporting vessels, which generally follow the same path each year (see Storrie et al. 2018), with circumnavigation of the main island in the archipelago, Spitsbergen, being the most commonly travelled path. Additionally, there is a risk of misidentification of species-young ringed and harbour seals in the water can be particularly challenging to differentiate-though the guides on marine cruise ship are generally very good naturalists. Another problem arises with observations of groups of animals, especially when numbers are high. Generally, reports of group numbers appeared to be crudely estimated when group size exceeded circa 20 animals; it is impossible to know the error margins of such observations. Another clear bias in the data is species popularity (preference) and predictability/sightability. Tour operators target known walrus haul-out sites because of their predictability and popularity, and they spend a lot of search effort looking for polar bears. The popularity of these charismatic megafauna species results in observations of these two species being over-represented in the database compared to less visible, less spatially predictable or less 'flashy' species. Smaller pinnipeds, for example, are less likely to be recorded consistently, even if they are sighted.

Given the biases discussed above, this sort of sighting data should not be used to assess relative abundance. Analyses must be kept to simple distributional assessments such as those reported herein, considering trends in reporting frequency when doing time series comparisons. KDEs for the number of animals were plotted in this study to get an idea of where the different species concentrate. But given uncertainties regarding actual group sizes for social species, only observations were used in the assessment of habitat characteristics and possible distributional changes through time. Another caveat to be mentioned when interpreting the results is that when observations are being reported to the MMSDB, the coordinates of the vessels at the time of observation are sometimes reported instead of the actual coordinates of the animal, so fine-scaled spatial analyses should not be attempted with this type of data.

The KDEs for walruses highlight their tendency to use coastal haul-outs during summer. Walruses were seen very close to shore, often around known terrestrial haulout sites, and over $90 \%$ of the observations occurred in areas shallower than $100 \mathrm{~m}$. These findings are consistent with the results of previous studies that have shown that walruses occupy coastal waters during summer in the Svalbard area, occupying shallow waters where mollusc beds occur and hauling out on land approximately $25 \%$ of the time (Gjertz \& Wiig 1992; Freitas et al. 2009; Hamilton, Kovacs et al. 2015). The walrus population in Svalbard is recovering from historical overharvesting and as their numbers are increasing, they are spreading back through their earlier range, expanding the number of haul-out areas they use (Kovacs et al. 2014; MOSJ 2019). Observation frequencies in the current study were high around previously identified haul-out sites, for example, on Prins Karls Forland, north-western Spitsbergen, Moffen and Torellneset (Gjertz \& Wiig 1994; Lydersen 
et al. 2008; Kovacs et al. 2014), while individual animalbased observations were highest around Storøya and Kvitøya in the north-east of the archipelago, where herds tend to be much larger (Gjertz \& Wiig 1994; Kovacs et al. 2014; Øren et al. 2018).

Observations of ringed seals in this study took place throughout the archipelago, though the majority of sightings and the greatest numbers of animals being seen close to the coast, especially where tidewater glaciers occur. However, ringed seals were also seen up to $200 \mathrm{~km}$ offshore in areas where there was drifting sea ice. Ringed seals were, perhaps not surprisingly, the most ice-affiliated resident species in Svalbard in this study, with only $40 \%$ of the observations of this species classified as open-water sightings. Ringed seals are known to have a sympatric lifestyle year-round (McLaren 1958). In Svalbard, ringed seals nurse their pups and offspring on land-fast ice, while in the broader Barents Sea region they also use drift ice as a birthing platform (Lydersen 1998; Wiig et al. 1999). Adult animals that breed in the fjords remain in their breeding areas throughout the year, while most young animals move offshore after the moulting period to the ice edge during the summer and autumn for foraging (Freitas et al. 2008; Hamilton, Lydersen et al. 2015; Hamilton et al. 2016; Hamilton et al. 2019). Tidewater glacier fronts are known hotspots for marine mammal and seabird foraging, because upwellings created by katabatic winds coming down from the glaciers and, to a lesser degree, subglacial discharge of freshwater cause concentrations of zooplankton and fish close to the glacier fronts (Hartley \& Fisher 1936; Lydersen et al. 2014; Sundfjord et al. 2017). Ringed seals made up 5-10\% of all recorded observations in all years of the study. During two unusual ice-years (2007 and 2008) when polar pack-ice lay along the north-west corner and north coast, relatively large numbers of ringed seals were seen hauled out on this ice in the summer, inflating the numbers of animals in those years for this relatively shy seal that spends most of its time in the water.

Bearded seals were observed most commonly close to land in shallow areas, deep into fjords along the west and north coasts of Spitsbergen, which is in keeping with their benthic foraging habits and strong affinity for ice when resting (e.g., Gjertz et al. 2000b; Hamilton et al. 2018, 2019). However, some bearded seals were seen in pack ice areas up to $300 \mathrm{~km}$ offshore north of Svalbard, but still over the continental shelf (Gjertz et al. 2000b; Hindell et al. 2012). Similar to ringed seals, bearded seals were often observed close to tidewater glacier fronts. Hamilton et al. (2019) compared the habitat use of ringed seals and bearded seals in Kongsfjorden and concluded that ringed seals have a much higher probability of hauling out during summer, which suggests a conflict with what was found in this study. But it is likely the shy nature of ringed seals, which respond to ships more readily by terminating a haul-out session, dictates their respective sighting rates (Kovacs \& Lydersen 2006). Additionally, bearded seals are much larger and darker than ringed seals, making them easier to detect at greater distances when they are resting on ice, creating a potential bias in the numbers seen.

Harbour seals were observed very close to the shore and at a high frequency around north-western Spitsbergen in this study. This is very much in line with previous studies that have found harbour seals in Svalbard to be tightly linked to the coast, occupying waters over the shelf (Blanchet et al. 2014, Hamilton et al. 2014). However, the current study shows that harbour seals are observed with increasing frequencies in the fjords and close to tidewater glacier fronts along the west coast of Spitsbergen, contrary to what has been reported from tracking studies (Blanchet et al. 2014). There were relatively few observations of harbour seals around Prins Karls Forland, which had earlier been identified as the most important area for the local harbour seal population (Reder et al. 2003; Hamilton et al. 2014). The reason for the low observation frequency around Prins Karls Forland in this study is most probably that boats simply travel within Forlandsundet, east of Prins Karls Forland, which is the main haul-out area for harbour seals in Svalbard, and seldom close to the west coast of the island because it is a protected bird reserve during the summer months. There were three single-animal observations of harbour seals on the east coast of Spitsbergen in this study. Harbour seals have been observed in the east of Spitsbergen in the past, but they are rare (Henriksen et al. 1997). One of the observations on Edgeøya was of an animal hauled out on a rock; a behaviour typical for harbour seals. However, this behaviour has in recent years also been observed for ringed seals in a few specific sites (Lydersen et al. 2017), which is a common species in eastern Svalbard. In the current study, $64 \%$ of the observations of harbour seals were from ice free waters, while only $1 \%$ of the observations were from areas with more than $40 \%$ ice, making them the least ice associated pinniped in Svalbard. This is consistent with tracking studies showing that harbour seals in Svalbard avoid areas with more than 50\% ice cover (Blanchet et al. 2014). Harbour seals were the species in this study that had the highest proportion of observations in shallow areas and/or on land. Only a small percentage of the harbour seal observations in the MMSDB were from areas deeper than $100 \mathrm{~m}$, which is consistent with previous studies (Krafft et al. 2002; Blanchet et al. 2014). 
Most polar bear observations in this study were close to, or on land in north-western Spitsbergen. This is consistent with the findings of Aars et al. (2017), who found that the density of bears on land is higher than that of bears on pack ice around Svalbard. Polar bears in this study also had high observation frequencies around the easternmost part of Spitsbergen and Edgeøya, and ice-covered areas north of Nordaustlandet. Hamilton et al. (2017) showed that polar bears spent less time in association with tidewater glacier fronts during summer in 2010-13 than during the period 2002-04. Consequently, they also spent less time associated with ringed seals, their preferred prey, during the summer months (Hamilton et al. 2017). Consistently, polar bears in this study were observed at a greater median distance from tidewater glacier fronts than the resident phocid seals. Polar bears are known to be largely solitary with the exception of mother and cub groups and the short liaison between adult females and males during the mating season (Rode \& Stirling 2018). But, some observations of polar bears included up to 20 individual animals in this study. These concentrations of animals ( 10 or more bears) were made either around whale or walrus carcasses, or around walrus resting sites. High concentrations of food, such as stranded whale carcasses, are known to result in such polar bear hotspots (Lønø 1970; Larsen 1986). It is possible that such concentrations of bears are becoming more common as the sea-ice declines reduce their range (Laidre et al. 2018).

Harp seals were observed in high frequencies north of Svalbard and in Hinlopenstretet. These two areas have not been described as particularly important for harp seals previously (Folkow et al. 2004). The increasing presence of harp seals in these areas is likely a result of the retreating summer sea ice edge and increased inflow of Atlantic Water to the region, opening up these areas for both harp seals and their main prey, capelin (Mallotus villosus) (Ingvaldsen \& Gjøsæter 2013). Harp seals are a very social species, sometimes occurring in the thousands, as seen in this study. Harp seals move into the Barents Sea seasonally from both the Greenland Sea and the White Sea stocks following the capelin distribution and feeding along the ice edge during the summer months (Haug et al. 1994; Folkow et al. 2004; Nordøy et al. 2008). Harp seals in this study were generally observed further from the coast relative to the resident species and in waters with low SST and relatively high sea-ice concentrations, consistent with their affinity to the sea-ice edge. The yearly mean latitude of harp seal observations increased significantly, and observation frequencies increased north and east of the Svalbard archipelago. This is likely a consequence of the fact that increased water temperatures since the early 2000s have markedly reduced the average sea-ice concentration north and east of Svalbard compared to the 1990s (Isaksen et al. 2016).

Most of the hooded seal observations in this study were made off the west and north coasts of Svalbard. These areas have previously been identified as foraging grounds during both summer and winter for hooded seals from the Greenland Sea stock (Folkow et al. 1996; Folkow \& Blix 1999; Vacquie-Garcia et al. 2017). Hooded seals in this study were the species observed with the highest median distance from the coast and the highest proportion of observations in areas $\geq 200 \mathrm{~m}$ deep. This is consistent with them being a relatively deep diving species that feeds pelagically at shelf breaks and along the sea-ice edge (Folkow \& Blix 1999; Vacquie-Garcia et al. 2017). Hooded seals were observed in areas with relatively high median SST $\left(4.2^{\circ} \mathrm{C}\right)$, compared to the other species. Though surprising, this finding is similar to a satellite tracking study of hooded seals in the North-east Atlantic that showed that this species seemed to associate with SSTs $\geq 4^{\circ} \mathrm{C}$ (Vacquie-Garcia et al. 2017). The low number of observations of hooded seals during most years in this study disallows conclusions being drawn regarding potential distribution shifts for this species.

Except for the harbour seal, all species in this study were observed north of $81^{\circ} \mathrm{N}$, with higher frequencies of sightings in northern areas during the recent period, when compared to the early period. This is probably a reflection of the location of the northern sea-ice edge, which has been retreating rapidly during the last three decades (Onarheim et al. 2014; Walsh et al. 2017; Lebedev et al. 2019). The ice edge is a highly productive area during spring, summer and autumn and is in many regards a hotspot for marine fauna (Sakshaug \& Skjoldal 1989). Harp seals follow the ice edge in the northern Barents Sea during summer and autumn, feeding pelagically and occasionally hauling out on the ice (Haug et al. 1994; Smith \& Stirling 2019), a habitat that they share with ringed seals (Wathne et al. 2000; Freitas et al. 2008; Hamilton, Lydersen et al. 2015). Ringed seals that undertake offshore feeding migrations prefer sea-ice concentrations close to $50 \%$ and prefer highly concentrated ice (80-100\%) over ice-free waters or waters with low seaice concentrations (Lone et al. 2019). In line with the results of this study, Hamilton, Lydersen et al. (2015) found that ringed seals feeding offshore during the period 2010-12 travelled on average $1^{\circ}$ further north than they did during 2002-03 before they reached ice.

There was a slight northward trend in latitude for bearded seal observations. The KDE plots also showed relative changes in observation frequency between the 
early and recent periods, for example, a decrease around Hornsund and an increase around north-western Spitsbergen. Much like ringed seals, bearded seals are ice-associated year-round, throughout their circumpolar distribution (Simpkins et al. 2003; Lydersen et al. 2014; Cameron et al. 2018; Hamilton et al. 2019); and decreases in both sea ice coverage and days of land-fast ice have been recorded between 2000 and 2014 in Hornsund and Isfjorden (Muckenhuber et al. 2016). It is possible that bearded seals have shifted their distribution from fjords in southern and western Spitsbergen to fjords in the northern part of Spitsbergen, where ice conditions have historically been more stable (Smith $\delta$ Lydersen 1991).

Harbour seal observations were more common in the north-western fjords (Smeerenburgfjorden and Kongsfjorden) during the recent period, but there was no significant northward trend for observations of this species, which is associated with the coast and not the drifting ice. The proportion of harbour seal observations comprised an increment from only $<1-2 \%$ of the total number of observations, during the first four years to $5-10 \%$ during the last half of the study. Harbour seals appear to be expanding their range and are increasingly found in the fjords in western Spitsbergen, a likely consequence of the increased presence of Atlantic prey species following an increase in the inflow of warm Atlantic water from the West Spitsbergen Current into these areas (Tverberg et al. 2014; Brand \& Fischer 2016). This could lead to competition for resources between harbour seals and ringed seals (in particular), as they share similar foraging strategies (Gjertz, Lydersen et al. 2001; Andersen et al. 2004; Bengtsson et al. 2020). Comparative studies of habitat use of the two species in fjords where their distributions overlap should be conducted in the near future.

The latitude of polar bear observations increased significantly and more bear sightings occurred in central areas along the coast of Spitsbergen and, north and east of Nordaustlandet. This corresponds well with findings of a study by Lone et al. (2018) that reported that the average number of days with suitable habitat related to sea ice for polar bears had increased in these areas during $2011-$ 15 compared to 1992-96. That study also found a general decrease in days with suitable habitat in most other regions (Lone et al. 2018) consistent with the decreases of observation frequency seen in this study.

Despite the lack of standardization of effort and a few other inherent biases, citizen science sighting programmes provide a cost-effective means to collect information regarding distributions of species through time, which are particularly useful at this time for identifying climate change impacts on ecosystems.

\section{Acknowledgements}

The authors thank the Norwegian Coast Guard, the IMR, the Association of Arctic Expedition Cruise Operators, the Governor of Svalbard's field teams and all others who contributed observations to the MMSDB. Siri Uldal developed the software frames for the MMSDB. Oddveig Ørvoll created the map of the study region. Claude Joiris and an anonymous reviewer provided comments that helped us improve the manuscript.

\section{Funding}

The MMSDB is a project run by the NPI. The analyses herein were undertaken as part of the EU grant Enabling the Adaptive Co-management of Social-Ecological Fjord Systems in the Arctic (FACE-IT) project (no. 860154).

\section{Disclosure statement}

The authors report no conflict of interests.

\section{References}

Aars J., Marques T.A., Lone K., Andersen M., Wiig Ø., Bardalen Fløystad I.M., Hagen S.B. \& Buckland S.T. 2017. The number and distribution of polar bears in the western Barents Sea. Polar Research 36, article no. 1374125, doi: 10.1080/17518369.2017.1374125.

Andersen S.M., Lydersen C., Grahl-Nielsen O. \& Kovacs K.M. 2004. Autumn diet of harbour seals (Phoca vitulina) at Prins Karls Forland, Svalbard, assessed via scat and fatty-acid analyses. Canadian Journal of Zoology 82, 1230-1245, doi: 10.1139/z04-093.

Bengtsson O., Lydersen C., Kovacs K.M. \& Lindström U. 2020. Ringed seal (Pusa hispida) diet on the west coast of Spitsbergen, Svalbard, Norway: during a time of ecosystem change. Polar Biology 43, 773-788, doi: 10.1007/ s00300-020-02684-5.

Blanchet M.A., Lydersen C., Ims R.A., Lowther A.D. \& Kovacs K.M. 2014. Harbour seal Phoca vitulina movement patterns in the High-Arctic archipelago of Svalbard, Norway. Aquatic Biology 21, 167-181, doi: 10.3354/ab00580.

Brand M. \& Fischer P. 2016. Species composition and abundance of the shallow water fish community of Kongsfjorden, Svalbard. Polar Biology 39, 2155-2167, doi: 10.1007/s00300-016-2022-y.

Cameron M.F., Frost K.J., Ver Hoef J.M., Breed G.A., Whiting A.V., Goodwin J. \& Boveng P.L. 2018. Habitat selection and seasonal movements of young bearded seals (Erignathus barbatus) in the Bering Sea. PLoS One 13(2), e0192743, doi: 10.1371/journal.pone.0192743.

Chacón J.E. \& Duong T. 2018. Multivariate kernel smoothing and its applications. Boca Raton, FL: CRC Press.

Derocher A.E., Wiig Ø. \& Andersen M. 2002. Diet composition of polar bears in Svalbard and the western Barents Sea. Polar Biology 25, 448-452, doi: 10.1007/ s00300-002-0364-0. 
Descamps S., Aars J., Fuglei E., Kovacs K.M., Lydersen C., Pavlova O., Pedersen Å.Ø., Ravolainen V. \& Strøm H. 2017. Climate change impacts on wildlife in a High Arctic archipelago-Svalbard, Norway. Global Change Biology 23, 490-502, doi: $10.1111 /$ gcb.13381.

Durner G.M., Douglas D.C., Nielson R.M., Amstrup S.C., McDonald T.L., Stirling I., Mauritzen M., Born E.W., Wiig Ø., DeWeaver E., Serreze M.C., Belikov S.E., Holland M.M., Maslanik J., Aars J., Bailey D.A. \& Derocher A.E. 2009. Predicting 21st-century polar bear habitat distribution from global climate models. Ecological Monographs 79, 25-58, doi: 10.1890/07-2089.1.

Folkow L.P. \& Blix A.S. 1999. Diving behaviour of hooded seals (Cystophora cristata) in the Greenland and Norwegian seas. Polar Biology 22, 61-74, doi: 10.1007/s003000050391.

Folkow L.P., Mårtensson P.E. \& Blix A.S. 1996. Annual distribution of hooded seals (Cystophora cristata) in the Greenland and Norwegian seas. Polar Biology 16, 179-189, doi: 10.1007/BF02329206.

Folkow L.P., Nordøy E.S. \& Blix A.S. 2004. Distribution and diving behaviour of harp seals (Pagophilus groenlandicus) from the Greenland Sea stock. Polar Biology 27, 281-298, doi: 10.1007/s00300-004-0591-7.

Fossheim M., Primicerio R., Johannesen E., Ingvaldsen R.B., Aschan M.M. \& Dolgov A.V. 2015. Recent warming leads to a rapid borealization of fish communities in the Arctic. Nature Climate Change 5, 673-677, doi: 10.1038/ nclimate2647.

Freitas C., Kovacs K.M., Ims R.A., Fedak M.A. \& Lydersen C. 2008. Ringed seal post-moulting movement tactics and habitat selection. Oecologia 155, 193-204, doi: 10.1007/ s00442-007-0894-9.

Freitas C., Kovacs K.M., Ims R.A., Fedak M.A. \& Lydersen C. 2009. Deep into the ice: over-wintering and habitat selection in male Atlantic walruses. Marine Ecology Progress Series 375, 247-261, doi: 10.3354/meps07725.

Gjertz I., Griffiths D., Krafft B.A., Lydersen C. \& Wiig Ø. 2001. Diving and haul-out patterns of walruses Odobenus rosmarus on Svalbard. Polar Biology 24, 314-319, doi: 10.1007/s003000000211.

Gjertz I., Kovacs K.M., Lydersen C. \& Wiig Ø. 2000a. Movements and diving of adult ringed seals (Phoca hispida) in Svalbard. Polar Biology 23, 651-656, doi: 10.1007/ s003000000143.

Gjertz I., Kovacs K.M., Lydersen C. \& Wiig Ø. 2000 b. Movements and diving of bearded seal (Erignathus barbatus) mothers and pups during lactation and post-weaning. Polar Biology 23, 559-566, doi: 10.1007/s003000000121.

Gjertz I., Lydersen C. \& Wiig Ø. 2001. Distribution and diving of harbour seals (Phoca vitulina) in Svalbard. Polar Biology 24, 209-214, doi: 10.1007/s003000000197.

Gjertz I. \& Wiig Ø. 1992. Feeding of walrus Odobenus rosmarus in Svalbard. Polar Record 28, 57-59, doi: 10.1017/ S0032247400020283.

Gjertz I. \& Wiig Ø. 1994. Past and present distribution of walruses in Svalbard. Arctic 47, 34-42, doi: 10.14430/arcticl269.

Hamilton C.D., Kovacs K.M., Ims R.A., Aars J. \& Lydersen C. 2017. An Arctic predator-prey system in flux: climate change impacts on coastal space use by polar bears and ringed seals. Journal of Animal Ecology 86, 1054-1064, doi: $10.1111 / 1365-2656.12685$.

Hamilton C.D., Kovacs K.M. \& Lydersen C. 2015. Year-round haul-out behaviour of male walruses Odobenus rosmarus in the northern Barents Sea. Marine Ecology Progress Series 519 , 251-263, doi: 10.3354/meps1 1089.

Hamilton C.D., Kovacs K.M. \& Lydersen C. 2018. Individual variability in diving, movement and activity patterns of adult bearded seals in Svalbard, Norway. Scientific Reports 8, article no. 16988, doi: 10.1038/s41598-018-35306-6.

Hamilton C.D., Kovacs K.M. \& Lydersen C. 2019. Sympatric seals use different habitats in an Arctic glacial fjord. Marine Ecology Progress Series 615, 205-220, doi: 10.3354/ meps 12917.

Hamilton C.D., Lydersen C., Ims R.A. \& Kovacs K.M. 2014. Haul-out behaviour of the world's northernmost population of harbour seals (Phoca vitulina) throughout the year. PLoS One 9(1), e86055, doi: 10.1371/journal. pone.0086055.

Hamilton C.D., Lydersen C., Ims R.A. \& Kovacs K.M. 2015. Predictions replaced by facts: a keystone species' behavioural responses to declining Arctic sea ice. Biology Letters 11, article no. 20150803, doi: 10.1098/ rsbl.2015.0803.

Hamilton C.D., Lydersen C., Ims R.A. \& Kovacs K.M. 2016. Coastal habitat use by ringed seals Pusa hispida following a regional sea-ice collapse: importance of glacial refugia in a changing Arctic. Marine Ecology Progress Series 545, 261-277, doi: 10.3354/meps11598.

Hartley C.H. \& Fisher J. 1936. The marine foods of birds in an inland fjord region in west Spitsbergen. Part 2. Birds. The Journal of Animal Ecology 5, 370-389, doi: 10.2307/1041.

Haug T., Nilssen K.T., Ien N. \& Potelov V. 1994. Seasonal distribution of harp seals (Phoca groenlandica) in the Barents Sea. Polar Research 13, 163-172, doi: 10.1111/j.17518369.1994.tb00446.x.

Henriksen G., Gjertz I. \& Kondakov A. 1997. A review of the distribution and abundance of harbor seals, Phoca vitulina, on Svalbard, Norway, and in the Barents Sea. Marine Mammal Science 13, 157-163, doi: 10.1111/j.17487692.1997.tb00622.x.

Hindell M.A., Lydersen C., Hop H. \& Kovacs K.M. 2012. Pre-partum diet of adult female bearded seals in years of contrasting ice conditions. PLoS One 7(5), e38307, doi: 10.1371/journal.pone.0038307.

Ingvaldsen R.B. \& Gjøsæter H. 2013. Responses in spatial distribution of Barents Sea capelin to changes in stock size, ocean temperature and ice cover. Marine Biology Research 9 , 867-877, doi: 10.1080/17451000.2013.775450.

IPCC 2014. Climate change 2014: synthesis report. Geneva: Intergovernmental Panel on Climate Change.

Isaksen K., Nordli Ø., Førland E.J., Łupikasza E., Eastwood S. \& Niedźwiedź T. 2016. Recent warming on Spitsbergeninfluence of atmospheric circulation and sea ice cover. Journal of Geophysical Research-Atmospheres 121, 11-913, doi: 10.1002/2016JD025606.

Jakobsson M., Mayer L., Coakley B., Dowdeswell J.A., Forbes S., Fridman B., Noormets R., Pedersen R., Rebesco M., Schenke H.W., Zarayskaya Y., Accettella D., Armstrong 
A., Anderson R.M., Bienhoff P., Camerlenghi A., Church I., Edwards M., Gardner J.V., Hall J.K., Hell B., Hestvik O., Kristoffersen Y., Christian M., Mohammad R., Mosher D., Ngheim S.V., Pedrosa M.T., Travaglini P.G. \& Weatherall P. 2012. The International Bathymetric Chart of the Arctic Ocean (IBCAO) version 3.0. Geophysical Research Letters 39, L12609, doi: 10.1029/2012GL052219.

Kohler J., König M., Nuth C. \& Villaflor G. 2018. Svalbard tidewater glacier front database. 2.07. Data set. Tromsø, Norway: Norwegian Polar Institute. doi: 10.21334/ npolar.2018.7cd67bla.

Kovacs K.M., Aars J. \& Lydersen C. 2014. Walruses recovering after $60+$ years of protection in Svalbard, Norway. Polar Research 33, article no. 26034, doi: 10.3402/polar. v33.26034.

Kovacs K.M. \& Lydersen C. 2006. Birds and mammals of Svalbard. Polar Handbook 13. Tromsø: Norwegian Polar Institute.

Kovacs K.M., Lydersen C., Overland J.E. \& Moore S.E. 2011. Impacts of changing sea-ice conditions on Arctic marine mammals. Marine Biodiversity 41, 181-194, doi: 10.1007/ s12526-010-0061-0.

Krafft B.A., Lydersen C., Gjertz I. \& Kovacs K.M. 2002. Diving behaviour of sub-adult harbour seals (Phoca vitulina) at Prins Karls Forland, Svalbard. Polar Biology 25, 230-234, doi: 10.1007/s00300-001-0330-2.

Laidre K.L., Born E.W., Atkinson S.N., Wiig Ø., Andersen L.W., Lunn N.J., Dyck M., Regehr E.V., McGovern R. \& Heagerty P. 2018. Range contraction and increasing isolation of a polar bear subpopulation in an era of sea-ice loss. Ecology and Evolution 8, 2062-2075, doi: 10.1002/ ece3.3809.

Laidre K.L., Stern H., Kovacs K.M., Lowry L., Moore S.E., Regehr E.V., Fergusson S.H., Wiig Ø., Boveng P., Angliss R.P., Born E.W., Litovka D., Quakenbush L., Lydersen C., Vongraven D. \& Ugarte F. 2015. Arctic marine mammal population status, sea ice habitat loss, and conservation recommendations for the 21 st century. Conservation Biology 29, 724-737, doi: 10.1111/cobi.12474.

Larsen T. 1986. Population biology of the polar bear (Ursus maritimus) in the Svalbard area. Oslo: Norwegian Polar Institute.

LaRue M.A., Ainley D.G., Pennycook J., Stamatiou K., Salas L., Nur N., Stammerjohn S. \& Barrington L. 2020. Engaging "the crowd" in remote sensing to learn about habitat affinity of the Weddell seal in Antarctica. Remote Sensing in Ecology and Conservation 6, 70-78, doi: 10.1002/ rse2.124.

Lebedev S.A., Kostianoy A.G. \& Popov S.K. 2019. Satellite altimetry of sea level and ice cover in the Barents Sea. Ecologica Montenegrina 25, 26-35, doi: 10.37828/ em.2019.25.3.

Leclerc L-M., Lydersen C., Haug T., Bachmann L., Fisk A. \& Kovacs K. 2012. A missing piece in the Arctic food web puzzle? Stomach contents of Greenland sharks sampled in Svalbard, Norway. Polar Biology 45, 1197-1208, doi: 10.1007/s00300-012-1166-7.

Lind S., Ingvaldsen R.B. \& Furevik T. 2018. Arctic warming hotspot in the northern Barents Sea linked to declining sea-ice import. Nature Climate Change 8, 634-639, doi: 10.1038/s41558-018-0205-y.

Lodi L. \& Tardin R. 2018. Citizen science contributes to the understanding of the occurrence and distribution of cetaceans in southeastern Brazil-a case study. Ocean $\theta$ Coastal Management 158, 45-55, doi: 10.1016/j. ocecoaman.2018.03.029.

Lone K., Hamilton C.D., Aars J., Lydersen C. \& Kovacs K.M. 2019. Summer habitat selection by ringed seals (Pusa hispida) in the drifting sea ice of the northern Barents Sea. Polar Research 38, article no. 3483, doi: 10.33265/polar. v38.3483.

Lone K., Merkel B., Lydersen C., Kovacs K.M. \& Aars J. 2018. Sea ice resource selection models for polar bears in the Barents Sea subpopulation. Ecography 41, 567-578, doi: $10.1111 /$ ecog.03020.

Lønø O. 1970. The polar bear (Ursus maritimus Phipps) in the Svalbard area. Oslo: Norwegian Polar Institute.

Lowther A.D., Kovacs K.M., Griffiths D. \& Lydersen C. 2015. Identification of motivational state in adult male Atlantic walruses inferred from changes in movement and diving behavior. Marine Mammal Science 31, 1291-1313, doi: 10.1371/journal.pone.0124754.

Lydersen C. 1998. Status and biology of ringed seals (Phoca hispida) in Svalbard. NAMMCO Scientific Publications 1, 46-62, doi: 10.7557/3.2980.

Lydersen C., Aars J. \& Kovacs K.M. 2008. Estimating the number of walruses in Svalbard from aerial surveys and behavioural data from satellite telemetry. Arctic 61, 119-128, doi: 10.14430/arctic31.

Lydersen C., Angantyr L.A., Wiig Ø. \& Øritsland T. 1991. Feeding habits of Northeast Atlantic harp seals (Phoca groenlandica) along the summer ice edge of the Barents Sea. Canadian Journal of Fisheries and Aquatic Sciences 48, 2180-2183, doi: 10.1139/f91-257.

Lydersen C., Assmy P., Falk-Petersen S., Kohler J., Kovacs K.M., Reigstad M., Steen H., Strøm H., Sundfjord A., Varpe Ø., Walczowski W., Węsławski J.M. \& Zajaczkowski M. 2014. The importance of tidewater glaciers for marine mammals and seabirds in Svalbard, Norway. Journal of Marine Systems 129, 452-471, doi: 10.1016/j. jmarsys.2013.09.006.

Lydersen C. \& Gjertz I. 1986. Studies of the ringed seal (Phoca hispida Schreber 1775) in its breeding habitat in Kongsfjorden, Svalbard. Polar Research 4, 57-63, doi: 10.3402/polar.v4il.6920.

Lydersen C., Gjertz I. \& Węsławski J.M. 1989. Stomach contents of autumn-feeding marine vertebrates from Hornsund, Svalbard. Polar Record 25, 107-114, doi: 10.1017/S0032247400010408.

Lydersen C., Vaquie-Garcia J., Lydersen E., Christensen G.N. \& Kovacs K.M. 2017. Novel terrestrial haul-out behaviour by ringed seals (Pusa hispida) in Svalbard, in association with harbour seals (Phoca vitulina). Polar Research 36, article no. 1374124, doi: 10.1080/17518369.2017.1374124.

Maslanik J.A., Fowler C., Stroeve J., Drobot S., Zwally J., Yi D. \& Emery W. 2007. A younger, thinner Arctic ice cover: increased potential for rapid, extensive 
sea-ice loss. Geophysical Research Letters 34, L24501, doi: 10.1029/2007GL032043.

Mauritzen M., Derocher A.E., Wiig Ø., Belikov S.E., Boltunov A.N., Hansen E. \& Garner G.W. 2002. Using satellite telemetry to define spatial population structure in polar bears in the Norwegian and western Russian Arctic. Journal of Applied Ecology 39, 79-90, doi: 10.1046/j.1365-2664.2002.00690.x.

McLaren I.A. 1958. The biology of the ringed seal, Phoca hispida, in the eastern Canadian Arctic. Ottawa: Fisheries Research Board of Canada.

Merkel B., Lydersen C., Yoccoz N.G. \& Kovacs K.M. 2013. The world's northernmost harbour seal population-how many are there? PLoS One 8(7), e67576, doi: 10.1371/journal.pone.0067576.

MOSJ (Environmental Monitoring of Svalbard and Jan Mayen) 2019. Walrus population. Accessed on the internet at http://www.mosj.no/en/fauna/marine/walrus-population.html on 5 March 2020.

Muckenhuber S., Nilsen F., Korosov A. \& Sandven S. 2016. Sea ice cover in Isfjorden and Hornsund, Svalbard (2000-2014) from remote sensing data. The Cryosphere 10, 149-158, doi: 10.5194/tc-10-149-2016.

NASA (National Aeronautics and Space Administration Goddard Space Flight Center, Ocean Ecology Laboratory, Ocean Biology Processing Group) 2014. Moderateresolution Imaging Spectroradiometer (MODIS) Aqua $11 \mu \mathrm{m}$ Day/Night Sea Surface Temperature Data. NASA OB.DAAC. Doi: data/10.5067/AQUA/MODIS/L3B/ SST/2014. Accessed on the internet at https://oceandata. sci.gsfc.nasa.gov/MODIS-Aqua/Mapped/Monthly/4km/ sst/ on 10 October 2019.

Nordøy E.S., Folkow L.P., Potelov V., Prischemikhin V. \& Blix A.S. 2008. Seasonal distribution and dive behaviour of harp seals (Pagophilus groenlandicus) of the White SeaBarents Sea stock. Polar Biology 31, article no. 1119, doi: 10.1007/s00300-008-0453-9.

Nuth C., Kohler J., König M., von Deschwanden A., Hagen J.O., Kääb A., Moholdt G. \& Petterson R. 2013. Decadal changes from a multi-temporal glacier inventory of Svalbard. The Cryosphere 7, 1603-1621, doi: 10.5194/ tc-7-1603-2013.

Onarheim I.H., Smedsrud L.H., Ingvaldsen R.B. \& Nilsen F. 2014. Loss of sea ice during winter north of Svalbard. Tellus A 66, article no. 23933, doi: 10.3402/tellusa.v66.23933.

Øren K., Kovacs K.M., Yoccoz N.G. \& Lydersen C. 2018. Assessing site-use and sources of disturbance at walrus haul-outs using monitoring cameras. Polar Biology 41, 1737-1750, doi: 10.1007/s00300-018-2313-6.

Pörtner H.-O., Roberts D.C., Masson-Delmotte V., Zhai P., Tignor M., Poloczanska E., Mintenbeck K., Alegría A., Nicolai M., Okem A., Petzold J., Rama B. \& Weyer N.M. (eds.) 2019. The ocean and cryosphere in a changing climate. A special report of the Intergovernmental Panel on Climate Change. Geneva: Intergovernmental Panel on Climate Change.

R Development Core Team 2018. A language and environment for statistical computing. Vienna: R Foundation for Statistical Computing.
Reder S., Lydersen C., Arnold W. \& Kovacs K.M. 2003. Haulout behaviour of High Arctic harbour seals (Phoca vitulina vitulina) in Svalbard, Norway. Polar Biology 27, 6-16, doi: 10.1007/s00300-003-0557-1.

Rode K. \& Stirling I. 2018. Polar bear: Ursus maritimus. In B. Würsig et al. (eds.): Encyclopedia of marine mammals. Pp. 743-746. Cambridge, MA: Academic Press.

Sakshaug E. \& Skjoldal H.R. 1989. Life at the ice edge. Ambio $8,60-67$.

Serreze M.C. \& Stroeve J. 2015. Arctic sea ice trends, variability and implications for seasonal ice forecasting. Philosophical Transactions of the Royal Society A 373, article no. 20140159, doi: 10.1098/rsta.2014.0159.

Silverman B.W. 1986. Density estimation for statistics and data analysis. London: Chapman and Hall.

Silvertown J. 2009. A new dawn for citizen science. Trends in Ecology $\theta$ Evolution 24, 467-471, doi: 10.1016/j. tree.2009.03.017.

Simpkins M.A., Hiruki-Raring L.M., Sheffield G., Grebmeier J.M. \& Bengtson J.L. 2003. Habitat selection by iceassociated pinnipeds near St. Lawrence Island, Alaska in March 2001. Polar Biology 26, 577-586, doi: 10.1007/ s00300-003-0527-7.

Skoglund E.G., Lydersen C., Grahl-Nielsen O., Haug T. $\&$ Kovacs K.M. 2010. Fatty acid composition of the blubber and dermis of adult male Atlantic walruses (Odobenus rosmarus rosmarus) in Svalbard, and their potential prey. Marine Biology Research 6, 239-250, doi: 10.1080/17451000903233755.

Smith T.G. \& Lydersen C. 1991. Availability of suitable land-fast ice and predation as factors limiting ringed seal populations, Phoca hispida, in Svalbard. Polar Research 10, 585-594, doi: 10.3402/polar.v10i2.6769.

Smith T.G. \& Stirling I. 2019. Predation of harp seals, Pagophilus groenlandicus, by polar bears, Ursus maritimus, in Svalbard. Arctic 72, 197-202, doi: 10.14430/arctic68186.

Spielhagen R.F., Werner K., Sørensen S.A., Zamelszyk K., Kandiano E., Budeus G., Husum K., Marchitto T. \& Hald M. 2011 . Enhanced modern heat transfer to the Arctic by warm Atlantic Water. Science 331, 450-453, doi: 10.1126/ science.1197397.

Stephenson F., Goetz K., Sharp B.R., Mouton T.L., Beets F.L., Roberts J. MacDiarmid A.B., Constantine R. \& Lundquist C.J. 2020. Modelling the spatial distribution of cetaceans in New Zealand waters. Diversity and Distributions 26, 495-516, doi: 10.1111/ddi.13035.

Stirling I. \& Derocher A.E. 2012. Effects of climate warming on polar bears: a review of the evidence. Global Change Biology 18, 2694-2706, doi: 10.1111/j.1365-2486.2012.02753.x.

Storrie L., Lydersen C., Andersen M., Wynn R.B. \& Kovacs K.M. 2018. Determining the species assemblage and habitat use of cetaceans in the Svalbard Archipelago, based on observations from 2002 to 2014. Polar Research 37, article no. 1463065, doi: 10.1080/17518369.2018.1463065.

Sundfjord A., Albretsen J., Kasajima Y., Skogseth R., Kohler J., Nuth C., Skarðhamar J., Cottier F., Nilsen F., Asplin L., Gerland S. \& Torsvik T. 2017. Effects of glacier runoff and wind on surface layer dynamics and Atlantic 
Water exchange in Kongsfjorden, Svalbard; a model study. Estuarine, Coastal and Shelf Science 187, 260-272, doi: 10.1016/j.ecss.2017.01.015.

Tonachella N., Nastasi A., Kaufman G., Maldini D. \& Rankin R.W. 2012. Predicting trends in humpback whale (Megaptera novaeangliae) abundance using citizen science. Pacific Conservation Biology 18, 297-309, doi: 10.1071/PC120297.

Tverberg V., Nøst O.A., Lydersen C. \& Kovacs K.M. 2014. Winter sea ice melting in the Atlantic Water subduction area, Svalbard, Norway. Journal of Geophysical ResearchOceans 119, 5945-5967, doi: 10.1002/2014JC010013.

Vacquie-Garcia J., Lydersen C., Biuw M., Haug T., Fedak M.A. \& Kovacs K.M. 2017. Hooded seal Cystophora cristata foraging areas in the Northeast Atlantic Ocean-investigated using three complementary methods. PLoS One 12(12), e0187889, doi: 10.1371/journal.pone.0187889.
Vann-Sander S., Clifton J. \& Harvey E. 2016. Can citizen science work? Perceptions of the role and utility of citizen science in a marine policy and management context. Marine Policy 72, 82-93, doi: 10.1016/j.marpol.2016.06.026.

Walsh J.E., Fetterer F., Scott Stewart J. \& Chapman W.L. 2017. A database for depicting Arctic sea ice variations back to 1850. Geographical Review 107, 89-107, doi: 10.1111/j.1931-0846.2016.12195.x.

Wathne J.A., Haug T. \& Lydersen C. 2000. Prey preferences and niche overlap of ringed seals Phoca hispida and harp seals $P$. groenlandica in the Barents Sea. Marine Ecology Progress Series 194, 233-239, doi: 10.3354/meps 194233.

Wiig Ø., Derocher A.I. \& Belikov S.E. 1999. Ring seal (Phoca hispida) breeding in the drifting pack ice of the Barents Sea. Marine Mammal Science 15, 595-598, doi: 10.1111/ j.1748-7692.1999.tb00828.x. 